\title{
Comparative myogenesis in teleosts and mammals
}

\author{
Giuliana Rossi · Graziella Messina
}

Received: 28 October 2013 / Revised: 17 February 2014 / Accepted: 6 March 2014 / Published online: 25 March 2014

(C) The Author(s) 2014. This article is published with open access at Springerlink.com

\begin{abstract}
Skeletal myogenesis has been and is currently under extensive study in both mammals and teleosts, with the latter providing a good model for skeletal myogenesis because of their flexible and conserved genome. Parallel investigations of muscle studies using both these models have strongly accelerated the advances in the field. However, when transferring the knowledge from one model to the other, it is important to take into account both their similarities and differences. The main difficulties in comparing mammals and teleosts arise from their different temporal development. Conserved aspects can be seen for muscle developmental origin and segmentation, and for the presence of multiple myogenic waves. Among the divergences, many fish have an indeterminate growth capacity throughout their entire life span, which is absent in mammals, thus implying different post-natal growth mechanisms. This review covers the current state of the art on myogenesis, with a focus on the most conserved and divergent aspects between mammals and teleosts.
\end{abstract}

Keywords Mouse and zebrafish - Myotome and dermomyotome $\cdot$ Primary and secondary myogenesis . Muscle fiber types $\cdot$ Satellite cells $\cdot$ Regeneration

\section{Introduction}

Skeletal muscle is the most abundant tissue in vertebrates, and it is used for locomotion, breathing, and energy metabolism. Different muscles have distinct features, including

G. Rossi $\cdot$ G. Messina $(\bowtie)$

Department of Biosciences, University of Milan, 20133 Milan, Italy

e-mail: graziella.messina@unimi.it anatomical structure, contractile and metabolic properties, fiber composition, blood supply, pattern of innervation, and embryonic origin. In addition, different muscles have different regenerative capacities [1] and are differentially affected in genetic disorders [2]. All the muscles of the limbs and trunk originate from the somites [3], whereas for the head, only the muscles of the tongue and some of the larynx and neck muscles are believed to be of somitic origin [4].

The fundamental events in myogenesis that are common to all vertebrates are the specification of the progenitor cells according to myogenic lineage, proliferation and migration, cell-cycle exit, differentiation, and fusion. The transcription factors (or myogenic regulatory factors, MRFs) that are responsible for the commitment of mesodermal cells to a muscle lineage (i.e., MyoD, Myf5) and for the initiation and maintenance of the terminal differentiation program (i.e., Myogenin, Mrf4) are highly conserved in teleosts and mammals [5]. Teleosts, and in particular zebrafish (Danio rerio), are useful for practical reasons, including ease of genetic manipulation and the large number and optical clarity of embryos/larvae that can be obtained, which allows cell movements to be observed in real time. Skeletal muscle development in teleosts shares several common features with that observed in amniotes: multistep development that involves the appearance of different classes of progenitor cells, the formation of myotome/dermomyotome, the molecular signals that drive commitment and differentiation, and the presence of muscle fibers with different contraction properties [6-8]. Nevertheless, myogenesis has some unique features in teleosts compared to mammals, which include the early stage of muscle commitment, presence of adaxial cells, different proportions of slow and fast fibers, and muscle growth throughout much of ontogeny. Moreover, on the basis of their different development, the main phases of myogenesis in teleosts consist of the 
embryonic-larval-juvenile and adult stages, whereas mammalian muscle development is conventionally divided into pre-natal and post-natal, and thus it is not always possible to make direct comparisons. In both mammals and teleosts, muscle development occurs through distinct myogenic waves that will be reported and discussed in this review, which will particularly focus on the conserved and divergent aspects between mammals and teleosts. Although we have tried to be as complete as possible, the wide topic covered prevents a full discussion of the original reports on which current knowledge in this field is based. Therefore, readers will also be referred to recent reviews and articles that cover specific aspects.

\section{Embryonic myogenesis}

Prenatal muscle development in mammals

\section{Anatomical structures}

During embryonic myogenesis, mesoderm-derived somites generate the first muscle fibers of the body, and, in subsequent waves, additional fibers are generated along the first muscular template [9]. Somites are transient mesodermal units that develop in a cranial to caudal succession from the segmental plate of the paraxial mesoderm [3]. As development proceeds, somites form into the distinct structures of a ventral sclerotome and a dorsal dermomyotome, which becomes the source of myogenic progenitors. Shortly after the onset of somitogenesis (at embryonic day E8.75 in mouse), some myogenic precursors give rise to terminally differentiated, mononucleated muscle cells (myocytes) of the primary myotome. The development of the primary myotome is a process in which precursors translocate from the dermomyotome to a ventrally located domain where they elongate along the axis of the embryo. This process has been widely studied, in particular in the avian embryo, although the role of the myotome during development of mammals remains unclear [4, 10-17]. In particular, in Myf5 $5^{\mathrm{nLacZ} / \mathrm{nLacZ}}$ mice, in which both Myf5 and Mrf4 expression is abolished, the primary myotome fails to form, whereas myogenesis proceeds normally, which would suggest that the myotome is dispensable for later muscle development [18]. In the dermomyotome, two regions can be further distinguished on the basis of their distance from the neural tube, and these give rise to the epaxial and hypaxial musculature. The epaxial dermomyotome is located dorsally and leads to the deep muscles of the back in amniotes, whereas the hypaxial dermomyotome is located superficially, laterally, and ventrally, and gives rise to the diaphragm, body wall, and limb muscles [19]. Evidence from several studies has demonstrated that the epaxial myogenic progenitors are dependent upon signals from axial structures, such as Sonic Hedgehog (Shh) and Wingless 1 (Wnt1), which mainly activate a myogenic program through the induction of Myf5. In contrast, hypaxial progenitors require signals from the dorsal ectoderm, such as Wnt7a, to promote MyoD-dependent myogenesis [19, 20]. This is consistent with the phenotype observed in the $M y f 5$ and $M y o D$ knock-out embryos, in which the former have epaxial defects and the latter show a delay in limb myogenesis, although the other myogenic determinant genes can drive an almost normal skeletal muscle development, as also explained by the primaxial-abaxial theory [21-23].

In mouse, the roles and interplay among the MRFs have been widely studied. Myf5 and MyoD have a largely redundant function in myoblast determination, so that deletion of the Myf5 or MyoD genes does not significantly affect muscle development $[22,24]$, but deletion of both Myf5 and $M y o D$ eliminates skeletal muscle lineage [25]. Of note, it has been demonstrated that Mrf4 is also involved in mouse muscle determination, as $M y f 5: M y o D$ double-mutant mice are actually partial triple mutants, because the deletion of the Myf 5 locus also compromises the genetically linked Mrf4 gene expression [26]. Indeed, in mutant embryos in which Mrf4 expression is preserved, embryonic myogenesis takes place in the absence of $M y o D$ and $M y f 5$, even if the muscle rapidly degenerates into the fetal stage of development [26]. This is in agreement with previous observations, which have shown that Mrf4 is transiently expressed during somitogenesis and later during fiber maturation [27]. Remarkably, the mouse Myogenin gene acts genetically downstream of $M y f 5$ and $M y o D$ to drive committed myoblasts towards terminal, biochemical muscle differentiation; if Myogenin is absent, myoblasts are correctly specified and positioned, but they fail to differentiate [28, 29]. Although Mrf4 is not essential for later muscle development, Mrf4:MyoD double-mutant mice are phenotypically similar to Myogenin mutants, which indicates that Mrf4 and MyoD have redundant roles in the activation of the differentiation program [30].

A broad spectrum of signaling molecules drives myogenesis during embryonic development [31]. These include morphogens that converge and act on a battery of transcription and chromatin-remodeling factors, which in turn drive cell progenitors towards a myogenic fate. On the basis of the concentration and the distance from the source, morphogens lead to different cellular fates [32]. As indicated above, Wnts and Shh are strongly involved in the positive specification of muscle progenitors in the somite. Mouse mutants for Wnt1, and the functionally redundant Wnt3a, have dermomyotome defects and reduced expression of the paired-homeobox transcription factor Pax3, as well as Myf5 [33]. Different findings in the literature show that 
Shh is essential for the commitment of dermomyotomal cells in MyoD/Myf5-positive myoblasts [34-36]. In contrast, bone morphogenic proteins (BMPs), which are members of the TGF- $\beta$ superfamily, have opposite effects on the myogenic program. In particular, Bmp4 is expressed in the lateral-plate mesoderm, and it retains muscle progenitors in an undifferentiated state by inducing Pax 3 expression, and thus delaying Myf5 and MyoD induction [37] (Fig. 1).

Notch signaling has been described as critical in the fate decisions of progenitor cells [38]. Notch mediates cell-cell communication, and has been described to inhibit myogenesis through inhibition of MyoD in cooperation with the DNA-binding protein RPB-J and the transcriptional repressor Hes1 [39, 40]. In particular, mutations in the Notch ligand Deltal or in RPB-J lead to precocious and robust muscle differentiation and loss of muscle precursors [41]. This suggests that, as for BMP4, Notch signaling promotes the expansion of myogenic progenitors while preventing differentiation.

The next level in the hierarchy of the control of myogenesis has as its major players the paired-homeobox transcription factors Pax3 and Pax7. All vertebrates have one of these genes, and it has been suggested that their evolutionary origin arose from the duplication of a common ancestral gene [42]. Pax3 and Pax7 are expressed in the dermomyotome, with the highest levels of Pax3 in the dorsal and ventral lips, and of Pax7 in the central domain [43]. Both Pax3 and Pax7 depend on the expression of sine-oculisrelated homeobox 1 (Six1) and Six4, which are currently considered to be at the apex of the genetic regulatory cascade that directs dermomyotomal progenitors towards the myogenic lineage [44, 45]. In contrast to chick embryos, where the migrating progenitor cells already express Pax7, in mouse, myogenic progenitors start to express Pax 7 only when they have already entered the limbs [46]. Indeed, in mouse, it is Pax3 alone that is required for delamination and migration of somatic precursor cells into the limb buds, through the signaling that involves scatter factor/hepatocyte growth factor (SF/HGF) and its receptor, the tyrosine kinase c-Met, which is a direct target of Pax3 [47] (Fig. 2). Mouse embryos that are homozygous for the Splotch Pax3 loss-of-function mutation do not develop the hypaxial domain of the dermomyotome, and, consequently, the limb and diaphragm muscles do not form [48-50]. Pax3 acts genetically upstream of MyoD, as no MyoD transcript can be detected in the limbs of Splotch mutant embryos. In particular, Pax3:Myf5:Mrf4 triple mutants have a dramatic phenotype that is not seen for the individual mutants: the body muscles are absent. MyoD does not rescue this triplemutant phenotype, as activation of $M y o D$ has been shown to be dependent on either Pax3 or Myf5 [51]. On the other hand, Pax7 appears to be dispensable during embryonic muscle development [52]. Of note, muscle development is more defective in the Pax3:Pax7 double knock-out, in which further muscle development is arrested and only the early embryonic muscle of the myotome is formed [53]. In addition, when Pax7 is knocked-into the Pax3 locus, most of the functions of Pax 3 are restored [54]. A more defined role for Pax3-expressing and Pax7-expressing myogenic populations was well described by the group of Kardon, and will be further discussed in the next section [55].

The head musculature has a different scenario, as it develops through different mechanisms. The craniofacial muscles have always been considered to be intricate muscles, and they have been less well explored. In recent years, remarkable progress has been made that has clearly revealed new concepts that have cast doubt on some of the classical dogma. Craniofacial skeletal muscles can be divided into distinct classes, and at variance with muscles of the trunk and limbs, these classes are not all of somitic
Fig. 1 Model of the early phases of myogenesis in mouse at embryonic day E10.5, illustrating how morphogens secreted by the surrounding domains can influence myogenic commitment. $D M$ dermomyotome, $D E$ dorsal ectoderm, $N T$ neural tube, $N C$ notochord, $L M$ lateral mesoderm, $M R F s$ myogenic regulatory factors

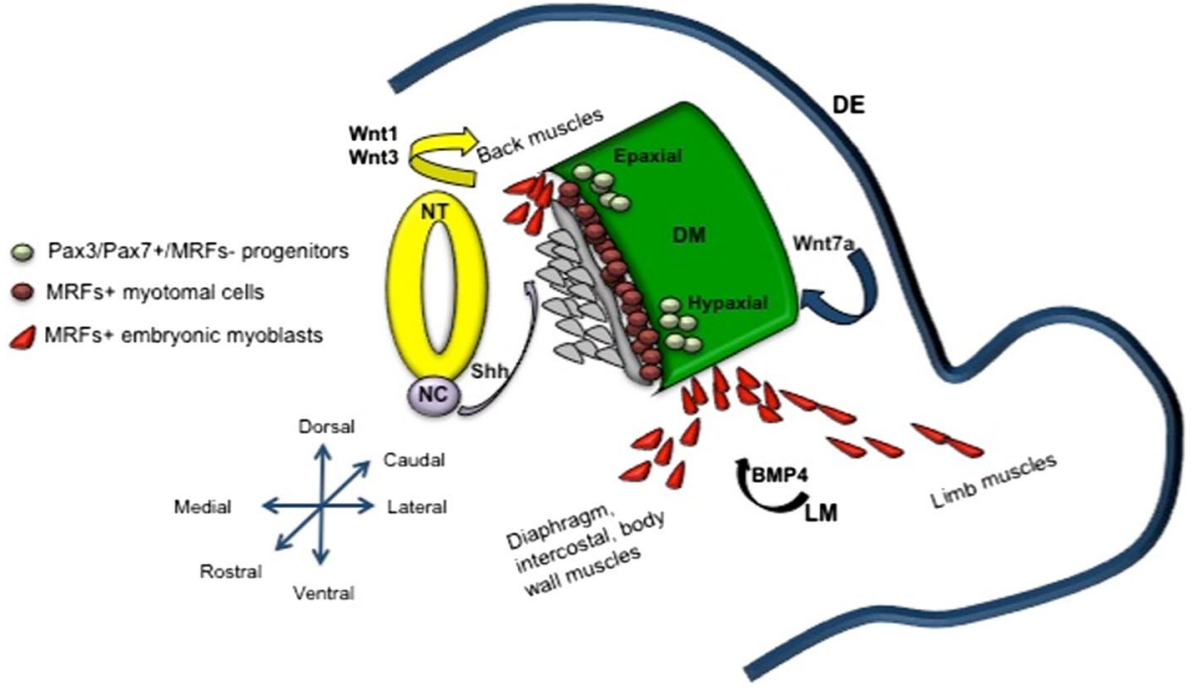


Fig. 2 Scheme of myogenic lineages, myogenic waves, and the molecules responsible for pre-natal muscle development in mouse. MRFs myogenic regulatory factors, d.p.c. days post-coitum. An indicative timing of murine development is shown

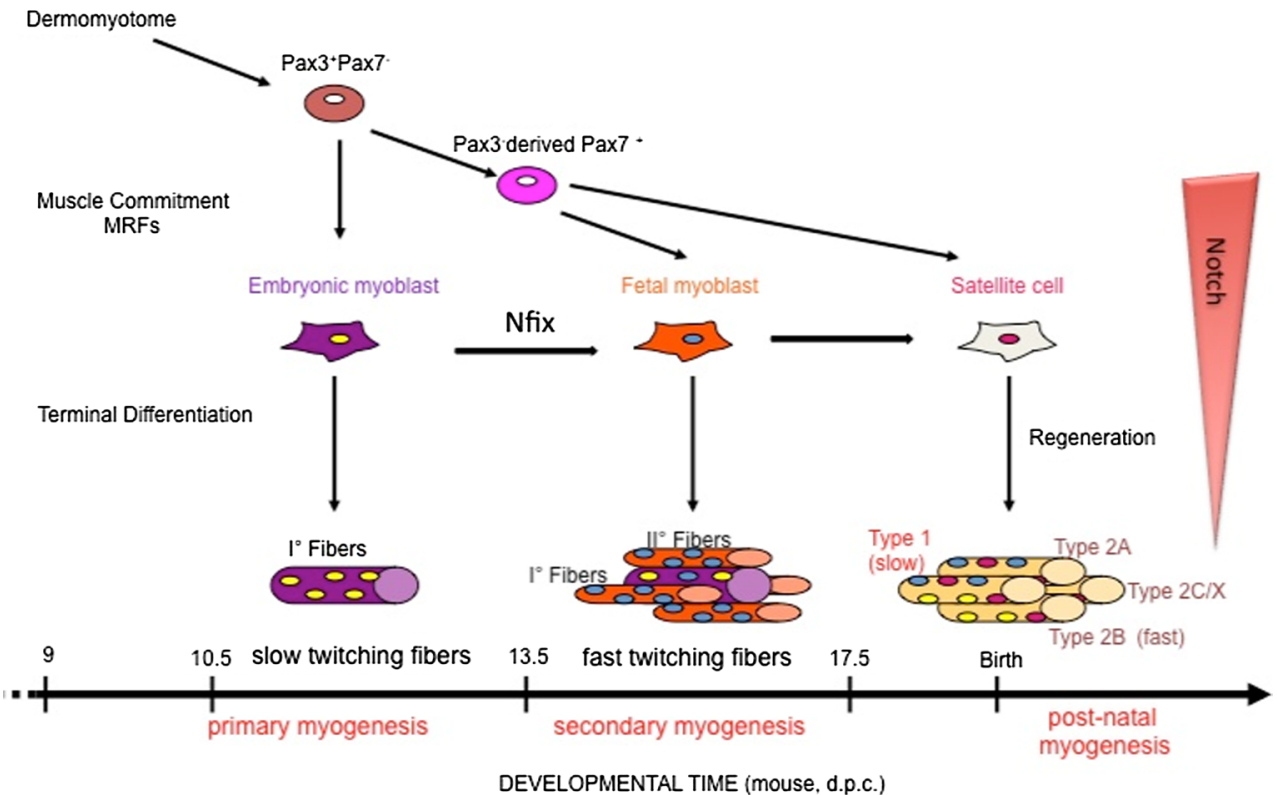

origin: somite-derived tongue and neck muscles; extraocular muscles that originate from the cranial paraxial and prechordal mesoderm; and branchiomeric muscles that are derived from the cranial mesoderm which is transiently present in the pharyngeal arches [56-58]. The first indication that the head muscles develop differentially from the muscles of the trunk and limbs came from the observation that murine Pax3:Myf5(Mrf4) mutants cannot form body muscles, whereas the head muscles are present [51]. In addition, signaling that has been widely described as promoting myogenesis in the trunk and limbs, such as the Wnt and BMP pathways, has inhibitory effects in the head $[59,60]$. Interestingly, Pax 3 , which has a fundamental role in trunk and limb muscle development [48, 53, 54], is not expressed in head muscles, and no muscular defects have been reported in the head for Pax3 mutant mice. Another fascinating difference is that Mrf4, which is important for myogenic determination of limb and trunk progenitors, cannot fulfil the same role in the head [26]. It is now known that all the head muscles depend on Pitx2 and Tbx1, which are transcription factors that contain homeodomains, and which positively regulate one another as well as Myf5; Pitx 2 and Tbx1 thus regulate the myogenic cascade [6163]. Recently, it has been shown that only the extraocular eye muscle, and not other head muscles, depends on the presence of both Myf5 and Mrf4, whereby MyoD cannot compensate for their absence [64]. In contrast, Tbx1 and Myf5 are necessary for branchiomeric muscle differentiation that converges on $\mathrm{MyoD}$, as in trunk myogenesis. Of note, a contribution to skeletal muscle development of the lateral plate mesoderm in chick and mouse has recently been demonstrated, where it has been shown that the somatopleure that is adjacent to the first three somites contributes to the development of some of the neck muscles [65].

\section{The different classes of myogenic populations in mammals}

It has been widely demonstrated in mammals that, like hematopoiesis, skeletal myogenesis occurs in successive, distinct-though-overlapping developmental stages that involve different cell populations and the expression of different genes. Skeletal muscle is, indeed, a heterogeneous tissue that is composed of individual muscle fibers that are diverse in size, shape, and contractile protein content, through which they can fulfill the different functional needs of the vertebrate body. This heterogeneity derives and depends at least in part upon distinct classes of myogenic progenitors; i.e., embryonic and fetal myoblasts and satellite cells (SCs). In particular, embryonic and fetal myoblasts control differentiation of the pre-natal musculature, whereas SCs are responsible for post-natal muscle growth and regeneration following muscle damage or injury [66-68]. Myoblast fusion into multinucleate muscle fibers begins at around E11 in mouse, and it characterizes the 'embryonic' or primary myogenesis that is necessary to establish the basic muscle pattern. Fetal myogenesis is characterized by growth and maturation of each muscle anlagen and by the onset of innervation. This second wave of myogenesis (also called secondary myogenesis) takes place between E14.5 and E17.5 in mouse, and it involves the fusion of fetal myoblasts either with each other, to form secondary fibers (initially smaller and surrounding primary fibers), or to a minor extent, with primary fibers. At the end of this phase, a newly formed basal lamina surrounds each individual fiber, and the SCs can then be morphologically 
identified as mononucleated cells that lie between the basal lamina and the myofiber plasma membrane. Embryonic and fetal cells and SCs were initially classified based on their in vitro characteristics. They differ in terms of their time of appearance, media requirements, response to extrinsic signaling molecules, drug sensitivity, and morphology of the myofibers they generate $[66,69]$. In addition, primary, secondary, and adult myofibers differ in their muscle contractile proteins, including their myosin heavy chain (MyHC) isoforms [70-72]. A genome-wide expression analysis carried out on purified embryonic and fetal myoblasts [67] identified many differentially expressed genes, which clearly shows that embryonic and fetal myoblasts are intrinsically different populations of myoblasts with distinct genetic programs.

We have demonstrated the pivotal role of the transcription factor nuclear factor IX, Nfix, in driving the transcriptional switch from embryonic to fetal myogenesis, and therefore from slow muscle to fast twitching and more mature muscle [73]. Nuclear factor one (NFI) proteins function as transcriptional activators and/or repressors of cellular and viral genes. In vertebrates, the $N f$ gene family consists of four closely related genes, known as $N f i a$, $N f i b, N f i c$, and $N f i x$, the last of which is the most expressed in muscle [74]. These encode for proteins with conserved $\mathrm{N}$-terminal DNA-binding and dimerization domains and C-terminal transactivation/repression domains. In vitro and in vivo loss-of-function (using siNfix in fetal myoblasts) and gain-of-function (expression of the exogenous Nfix2 isoform in embryonic myoblasts) approaches have revealed the crucial role of Nfix in driving the transcriptional switch from embryonic to fetal myogenesis. In particular, we showed that Nfix, the expression of which in fetal muscle is in part activated by Pax7, can act through different pathways to switch off embryonic specific markers, such as slowMyHC (by down-regulation of the slowMyHC activator NFATc4), and to activate fetal-specific proteins, such as $\beta$-enolase and MCK [73]. Our study thus provided the first evidence that a single factor is responsible for the differential gene expression that transforms the primary muscle anlagen (due to embryonic myogenesis) into a more mature and organized muscle (fetal myogenesis) [73].

Although these myoblast classes are functionally distinct, it was not clear whether they develop from common or different progenitors. As indicated above, Pax3 and Pax7 are markers for somitic myogenic precursors and are crucial for myogenic determination. In a very elegant study, the group of Kardon used Pax3-cre and Pax7-cre diphtheria toxin mouse strains to clearly demonstrate the outcome of specific ablation of these respective cell populations [55]. Here, Hutcheson et al. clearly demonstrated that loss of the Pax 3 lineage is embryonically lethal and prevents the emergence of Pax7-positive cells, whereas ablation of Pax7-expressing cells only leads to defects in the later stages of development, which leads to smaller muscles with fewer myofibers at birth. Thus, they clearly defined Pax3positive cells as the progenitors of embryonic myoblasts that lead to the development of primary fibers in the limb, to which Pax7-positive cells successively contribute by forming secondary fibers and establishing the SC pool [55].

Although these and other studies have established the origins and features of these myogenic populations, it is still not clear whether there is a single self-renewing population in the embryo that is sustained to adulthood, or whether intermediate, stage-specific populations arise that lead to the populations of the corresponding developmental stages. A recent study supports the former scenario. Using different genetic tools, the group of Tajbakhsh demonstrated that Notch signaling via the Rbpj-dependent pathway is active throughout development in muscle founder cell populations [75]. Notch activity is necessary and sufficient for the maintenance of muscle progenitor cells, and it allows them to still be receptive to specification and differentiation cues during development. Specifically, during embryonic myogenesis, the upstream myogenic subpopulation that expresses high levels of Pax7 (referred to as Pax$7^{\text {High }}$ ) is maintained and expanded by high Notch activity, and their following differentiation is induced by the MRFs, which results in down-regulation of Notch and Pax7 and the formation of myofibers of the corresponding developmental stage. Remarkably, although they are correctly committed, myoblasts with high Notch activity fail to terminally differentiate in embryonic and fetal trunk and limbs, and also in the head (Fig. 2).

\section{The heterogeneity of primary and secondary fibers}

As indicated above, muscle fiber formation in vertebrates is a multiphasic process that is characterized by heterogeneous fiber types, on the basis of the expression of the different MyHC isoforms. The classification is based on the speed of contraction of the muscle fibers, which mainly depends on the ATPase activity. In rodents, a single $I / \beta$ slow $M y H C$ gene has been identified, the gene product of which is characterized by slow ATPase activity, whereas the embryonic and perinatal MyHC isoforms are progressively replaced post-natally with the three adult fast MyHCs, IIa, IIx, and IIb [76]. The boundaries between the different classes of fibers are not absolute and intermediate fibers can co-express different MyHC isoforms. In particular, during pre-natal muscle development, primary muscle fibers express embryonic (fast) and $\mathrm{I} / \beta$ slowMyHC. In contrast, secondary muscle fibers express the fast embryonic and perinatal isoforms from their inception, and, with the exception of the soleus muscle, they do not express the I/ $\beta$ slowMyHC. Thus, in general, mammalian primary 
muscle fibers are programmed for a mainly slow phenotype, whereas secondary muscle fibers adopt a fast phenotype $[66,67]$. This diversification of muscle fibers starts during the embryonic stages, independently of neural influence, whereas, during early post-natal development and in the adult, motor neuron and the activities of various hormones can modulate the fiber type profile, and in particular that of thyroid hormone. In recent years, many key factors that control muscle fiber-specific gene programs have been identified, such as the NFAT isoforms [77]. In addition, Nfix indirectly represses slowMyHC expression through direct inhibition of the NFATC4 promoter [73].

However, the molecular and cellular mechanisms by which muscle fiber diversity is achieved during development are still poorly understood. Sox6 belongs to the group $\mathrm{D}$ of Sox factors, and it is a transcriptional repressor that has been shown to have an important role in the development of several tissues, including skeletal muscle [78]. Different studies have demonstrated that Sox6-null muscle has increased levels of $\mathrm{I} / \beta$ slowMyHC and a general switch towards a slower phenotype [79-81]. It has been shown that Sox6 exerts its function by direct binding to the $I / \beta$ slowMyHC promoter [79, 80, 82]. Moreover, the group of Olson identified a microRNA (miR)-mediated transcriptional regulatory network. Here, miR-499 and miR-208 are intronically encoded within the slowMyHC genes, and they act through a reciprocal negative-feedback loop to target Sox6, which thus promotes a fast-to-slow myofiber-type switch [81]. As Sox6 does not have any known regulatory domains, the specific mechanisms of repression involved here remain to be elucidated.

In mouse embryo, it has also been demonstrated that the Six 1 and Six 4 homeodomain transcription factors are required for the correct transcription of fast muscle genes in the myotome, as, in Sixl:Six4 double mutants, the slow program is activated and the fast muscle genes are not expressed [83].

Embryonic myogenic development in zebrafish

\section{Somite development and embryonic myogenesis}

In teleosts, the overall process of somitogenesis is similar to mammals, but the timing and the specification of myogenic progenitors show particular differences.

In zebrafish, the first somite forms shortly after the end of gastrulation [84]. The paraxial mesoderm develops from the cells around the edge of the early gastrula, which converge towards the dorsal side to form the paraxial mesoderm, adjacent to the axial mesoderm (Fig. 3). As somitogenesis proceeds, the trunk begins to lift off the yolk and the tail extends. At the end of the first day of development, somitogenesis is complete, and the somites are subdivided into sclerotome and myotome, where the myotome is already innervated and functional [84].

One of the most intriguing differences from mammals is that, in zebrafish, the myoblasts become committed to myogenic progenitor cells before the onset of somitogenesis.
Fig. 3 Scheme of embryonic muscle development in zebrafish, showing a schematic flow chart of early muscle development where the main patterning events have been defined. h.p.f. hours post-fertilization, $A B C$ anterior border cells, Row 1 row of cells 1

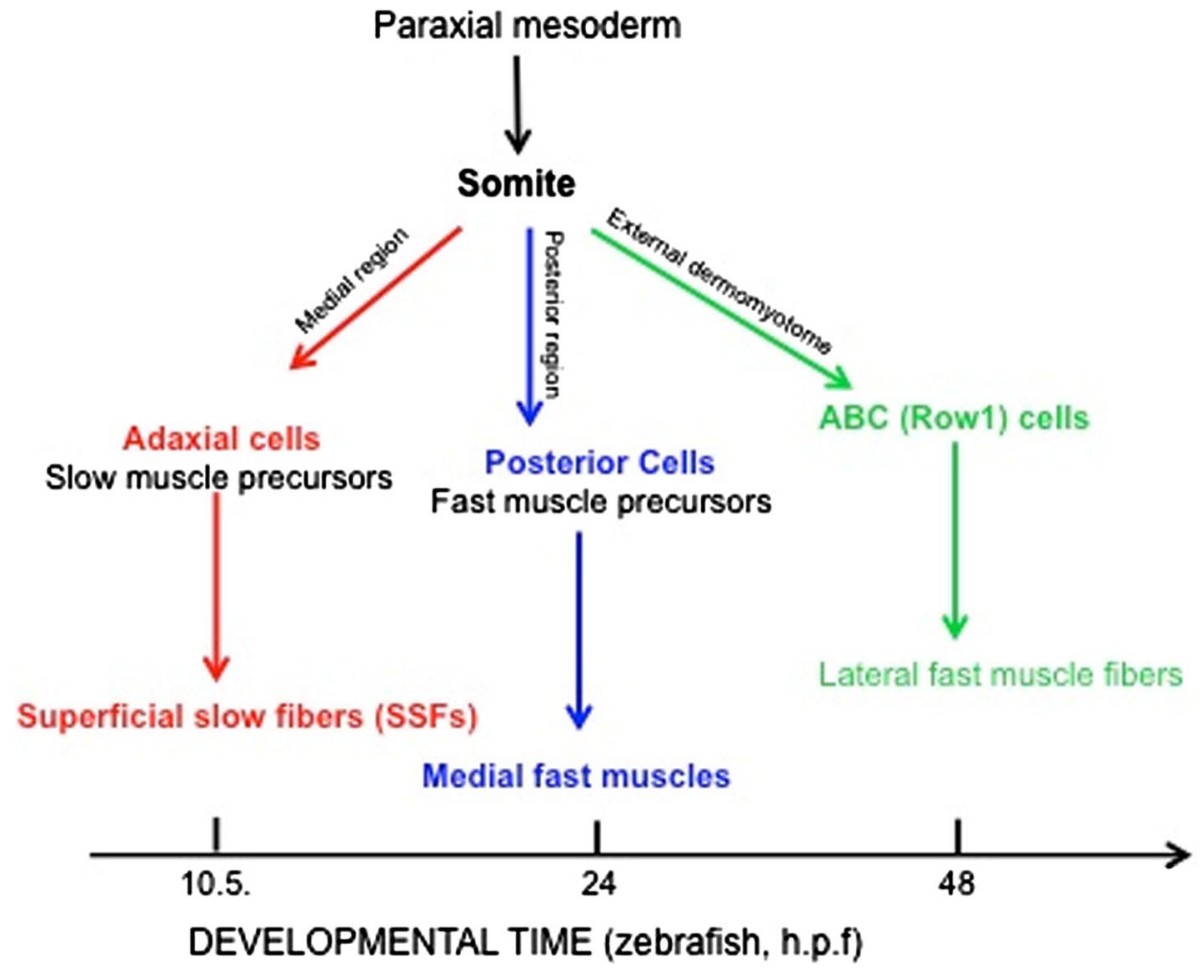


The first wave of myogenesis comes from a medial myoDpositive and myf5-positive presomitic mesoderm cell population that lies adjacent to the notochord, known as the adaxial cells [85]. After somite formation, these adaxial cells migrate radially from the notochord to form a layer of superficial slow fibers on the myotomal surface that uniquely express the transcription factor Prox 1, and slowMyHC (smyhcl) [8]. Unlike adaxial cells, the lateral population of cells in the segmental plate, known as the lateral presomitic cells, does not express detectable levels of $m y o D$ and myf5 until somite formation. After slow-fiber precursor migration and differentiation, the lateral presomitic cells in the deeper and posterior part of the somite differentiate into medial fast muscle fibers, which then form the second component of the primary myotome [86-88]. At $24 \mathrm{~h}$ postfertilization (hpf), the segmentation is complete and a functional myotome is formed.

After this embryonic period, new muscle fibers differentiate into several body locations in a process called stratified hyperplasia, or secondary myogenesis (48-72 hpf) [8, 89]. Indeed, in teleosts, muscle growth occurs both by hypertrophy, due to the increase in size of pre-existing muscle fibers throughout life [6], and by hyperplasia, due to the activity of myogenic progenitor cells in the larval stage [90]. As in amniotes, continuous growth of the myotome relies on myogenic progenitor cells that originate from the zebrafish dermomyotome [7].

The dermomyotome was initially characterized in the late nineteenth century on the basis of anatomical and morphological evidence, and, in teleosts, it has received renewed interest only recently [91]. As in amniotes, the teleost dermomyotome expresses Pax3 and Pax7, although in zebrafish it consists of a flattened epithelium with no obvious dorsal and ventral lips [7, 92]. As the adaxial cells and posterior somite cells express the MRFs very early, are post-mitotic before their incorporation into somites and do not express Pax 3 and Pax7, this suggests that the primary myotome develops independently of the dermomyotome $[86,90]$. Indeed, interestingly, in zebrafish, the first muscle fibers elongate before the dermomyotome forms, at variance with amniotes, in which the first muscle fibers elongate after the dermomyotome development.

The cells from which the dermomyotome in teleosts originate have been defined as the anterior border cells, to distinguish them from the medial and posterior region of the somite [86]. Moreover, because these myoD-negative anterior border cells form a single row of epithelium that is external to the myotome, they have also been called Row 1 cells (Fig. 3) [90]. During late segmentation and early larval stages, dermomyotomal cells proliferate and give rise to the secondary myotome: the mesenchyme cells of the dorsal fin, fin muscle, and dermis. As indicated above, the earliest growth of the primary myotome occurs through stratified hyperplasia, which produces layers of fibers with different cross-sectional areas. The dermomyotome Pax7-expressing cells move from the outside surface to the inside surface of the slow muscle monolayer and originate new fast muscle fibers that are initially added in the region between the slow and fast fibers $[86,90]$. Interestingly, teleosts retain an epithelial layer of Pax7-undifferentiated-positive cells into their early juvenile period, thus leading to a continuous contribution to post-larval muscle growth. A wide and deep comparative analysis of the zebrafish dermomyotome was provided by Stellabotte and Devoto [91] (Fig. 3).

In zebrafish, it has been reported that either Myf5 or MyoD are sufficient to promote slow muscle formation from adaxial cells, and that MyoD is required for fast muscle differentiation [92, 93]. Indeed, down-regulation of both MyoD and Myf5 abolishes slow muscle development in the early myotome, whereas MyoD, but not Myf5, cooperates with $\mathrm{Pbx}$ homeodomain proteins to promote a fast myogenic program [94]. Interestingly, and at variance with mammals, Mrf4 does not control early myogenesis in zebrafish, as Mrf4 is expressed as late as Myogenin, and therefore has no role in muscle commitment [95-97]. Lack of skeletal muscle in the double myf5:myoD mutants shows that endogenous zebrafish Mrf4 cannot drive early myogenesis in the myf5:myoD double morphants [98], unlike the situation in mouse [26]. Of note, the injection of mrf4 mRNA, but not myogenin mRNA, can rescue and drive myogenesis via the robust activation of endogenous myoD [97]. Additionally, zebrafish MyoD can activate mrf4 in myf5-mutant embryos, which indicates a positive-feedback loop between $m y o D$ and $m r f 4$ in zebrafish; such a positive-feedback loop has not been reported in any other species to date [97].

The head musculature in zebrafish has recently been explored, although there is little evidence available on this topic. Almost all the cranial muscles contain both slow and fast muscle fibers, and, as in the trunk, slow fibers are found only in the periphery of each muscle [99]. Additionally, the proportion between slow and fast muscles varies through development, with a decrease in the proportion of slow muscle with ontogeny. The transcription factor Six 1a has an essential role in craniofacial myogenesis, as it is necessary for MyoD and Myogenin expression in the head [100]. Remarkably, and at variance with what is observed in mammals, in zebrafish, MyoD is necessary to drive the cranial musculature, as myod morphants show reduced muscle fibers in the head [98]. The mechanisms of action of Six 1a in the development of the head muscle were well discussed in Lin et al. [100].

\section{Pivotal role of Hedgehog signaling in teleost myogenesis}

As described for mammals, cell fate in the somite of zebrafish also depends on signaling factors released by 
the surrounding tissues, which thus regulate the balance between proliferation and differentiation. Of note, Hedgehog secreted by the notochord and ventral spinal cord has a crucial, and almost unique, role during myogenesis in zebrafish. Three zebrafish mutants, floating head (fh), no tail (ntl), and bozozok (boz), have defects in the notochord, and these show variable deficiencies in early adaxial cells, myoD expression, and development of slowMyHC fibers during the first 24 hpf [88]. In support of this evidence, overexpression of hedgehog mRNA in wild-type embryos results in a dramatic expansion of slow muscle at the expense of fast muscle. Conversely, defective slow muscle development in notochord mutants can be rescued by re-expression of wild-type hedgehog mRNA [88]. Moreover, overexpression of Patched, which inhibits Hedgehog signaling, as well as a series of different zebrafish mutants of the Hedgehog pathway, promotes defects in slow fiber development, thus supporting the crucial and unique role of Hedgehog in determining the slow muscle fate of adaxial cells [101, 102].

Intriguingly, the group of Devoto demonstrated that Hedgehog also has a later role in the regulation of differentiation of the Pax3- and Pax7-positive dermomyotomal population [103]. Using various tools to inhibit the Hedgehog pathway, it has been demonstrated that Hedgehog does not regulate the induction of Pax 3 and Pax7 expression in the dermomyotome, but instead affects the down-regulation of Pax3 and Pax7 which is a necessary step for the subsequent expression of $m y o D$ and for differentiation into fast muscle fibers (Fig. 4). Moreover, it has been shown that the effect of Hedgehog on embryonic slow and fast muscle fibers can be distinguished both pharmacologically and genetically: slow muscle fibers require earlier Hedgehog signaling and are dependent on the downstream Hedgehog

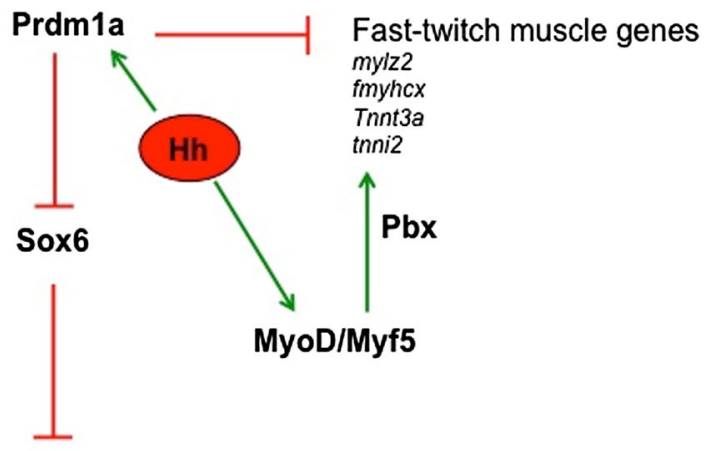

Slow-twitch muscle genes smych1 prox1a

tnnc1b

Fig. 4 Schematic representation of the molecular pathways that regulate fiber type diversification in zebrafish. In italics, specific slow and fast genes; see text for details effector gli2, whereas fast muscle differentiation requires later Hedgehog signaling, and these fibers are only in part dependent on gli2. Intriguingly, Feng et al. [103] created genetic mosaics by transplanting either wild-type or Hedgehog-unresponsive $\operatorname{smu}\left(\right.$ smo $^{-1-}$ cells into wild-type embryos, through which they showed that the requirement for Hedgehog signaling is cell autonomous in the dermomyotome and is not mediated by another signal released by the adjacent slow muscle fibers. It is possible that the role of Hedgehog in mammals is more likely to be analogous to the second action of Hedgehog in zebrafish, which is on Pax3- and Pax7-positive dermomyotomal cells.

As in mammals, the activities of TGF- $\beta$ family members, such as Bmp4, oppose the actions of Hedgehog signaling on adaxial cells [104]. It has recently been observed that even the dermomyotome is responsive to Bmp2b and Bmp4, the actions of which increase the number of Pax $7^{+}$ myogenic progenitors, which thus delays muscle differentiation. Of note, while BMP overexpression is sufficient per se to interfere with terminal differentiation, BMP inhibition does not affect this process, which thus indicates that other factors can redundantly inhibit myogenic differentiation [105]. So, despite important differences in the fate of myoblasts within the somite in mammals and teleosts, the opposite actions of Hedgehog and BMP4 in somite patterning appear to be conserved throughout vertebrate evolution. Little is known or has been explored relating to the role of Wnt signaling in zebrafish myogenesis.

\section{Control of muscle fiber type diversity during embryonic development}

As indicated above, different fiber type compositions reflect and respond to the different needs of an individual. This diversity is influenced by external stimuli and cues, and it is also finely controlled by signaling pathways during development. As in mammals, even fiber type development and distribution in zebrafish is driven by defined molecular pathways that have been extensively studied in the last 15 years [106].

The studies from the group of Ingham have defined the transcriptional regulatory network at the base of fiber type diversification [106-108]. With Hedgehog signaling added to a slow myogenic program, this network involves the repressor activity of Prdm1a, a zinc-finger DNA-binding protein that can promote the slow-twitch differentiation program by direct inhibition of the fast specific genes, such as mylz2, fastMyHCx, tnnt3a, and tnni2. In contrast, Prdm1 appears not to bind promoters of typical slow genes, such as proxla, smyhcl, and slow troponin c, and functions instead by repression of the transcription factor sox6 [107]. As in mammals, Sox6 in zebrafish is expressed in fast-twitch progenitors, and it can repress slow-twitch genes [79, 
106-108]. Recently, Wang et al. defined a gene regulatory network that shows temporal control of the slow-specific program through a post-transcriptional feedback circuit that involves the activity of miR-499. As in mammals, miR-499 arises from an intronic region of the slowMyHC gene and specifically inhibits sox6 [108] (Fig. 4). Intriguingly, and at variance with what has been observed in mouse, the loss of Sox6 in zebrafish does not lead to ectopic expression of all the slow genes in the fast fibers, as smyhcl gene expression remains confined to slow muscle fibers [107].

Although there has been sox6 gene duplication in most teleost genomes, this duplication did not occur in zebrafish [106]. This leads to the assumption of another repressor that is potentially involved in the repression of smyhcl in non-adaxial cells.

Although the majority of the fish musculature comprises fast-twitching myofibers, less is known or has been investigated relating to the signaling responsible for fast-muscle specification. In zebrafish, Six 1 and, most importantly, the $\mathrm{Pbx}$ homeodomain transcription factors have been implicated in the control of the onset of fast-muscle differentiation. In particular, it was recently demonstrated that $\mathrm{Pbx}$ acts by directing MyoD to a subset of fast-muscle genes, which counteracts the repressing action of Prdm1a [94, 109, 110].

To date, different aspects diversify fiber type determination in mammals and zebrafish. First, while in zebrafish the adaxial cells give rise to only slow muscle [8], in amniotes, the slow myogenic program is not determined by a specific myogenic population. Slow and fast muscle fibers can both arise from the same cell type, which only depends on the determination signals that they receive. Secondly, in mammals, slow and fast myofibers are both multinucleated, although they differ in muscle size [66], whereas in fish, the slow-twitch progenitors are fusion incompetent and differentiate into mononucleated fibers, at variance with their fast-twitch myoblasts $[8,111]$. In addition, although Prdm1 is highly conserved among vertebrates and its expression is dependent on Hedgehog signaling, the pivotal role of Prdm1a in the regulation of slow muscle differentiation in zebrafish is not conserved in mammals, in which its absence does not impair correct fiber type determination and Sox6 expression [106, 112].

\section{Myogenic waves in zebrafish}

We have already indicated that amniotes have multiple, distinguishable waves of myogenic differentiation during pre-natal muscle development, and that these myogenic waves tightly depend on defined embryonic and fetal myogenic populations that share distinct genetic programs $[66,67,73]$. In teleosts, the boundaries are less defined, and the main differences arise because different myogenic populations promote distinct myogenic programs that are defined on the basis of the positions where these populations will form muscle fibers. At the end of the segmentation period in zebrafish ( $24 \mathrm{hpf})$, the events that lead to a functional embryonic myotome can be defined as the primary myogenic wave, the timing and characteristics of which cannot be directly compared to mouse embryonic/ primary myogenesis. Following this primary myogenic development, the secondary muscle fibers differentiate in several body locations in a process called stratified hyperplasia or secondary myogenesis (48-72 hpf) $[6,8,89]$. This is more similar to mouse primary/secondary myogenesis on the basis of the source of the myogenic populations (the dermomyotome), the requirement for Hedgehog signaling, and the formation of multinucleated slowMyHC. Nevertheless, a convincing comparison is still difficult. As indicated above, we identified the transcription factor Nfix as a master switch regulator of the transcriptional transition from embryonic to fetal muscle [73]. According to these data, if Nfix has a similar role in zebrafish, this would allow better definition of the myogenic waves in teleosts. We demonstrated that there is a zebrafish ortholog of Nfix, nfixa, the mRNA of which strongly increases at the onset of the secondary myogenic wave, as in mammals [113]. Indeed, using a loss-of-function approach to specifically abrogate the nfixa function in vivo, we showed that lack of nfixa does not perturb the primary myogenic wave, as the injected embryos showed normal somite numbers and size, normal MRF expression, and normal superficial slow fiber formation. In contrast, this loss of nfixa led to effects that were evident from $48 \mathrm{hpf}$ that caused a marked impairment of the second myogenic wave: embryo immobility, persistence of smyhcl expression, lack of a $\mathrm{Pax} 7^{+}$population, and muscle disorganization. As in mammals, Nfixa acts through conserved mechanisms that include nfatc4-mediated regulation of slowMyhC expression and cooperation with the Mef2 proteins [113]. Of note, we also observed that the nfixa-morphants did not move and swim correctly due to impaired development of the sarcoplasmic reticulum, which was not observed in Nfix-null fetuses [73, 113]. Therefore, although the mechanisms underlying the second myogenic wave in zebrafish have been poorly characterized, our data shed light on the conserved functions of Nfix in this process, and on this first comparison between the second myogenic wave in zebrafish and fetal myogenesis in mammals.

Post-natal myogenesis in mammals

\section{Amniote satellite cell properties}

Post-natal skeletal myogenesis in mammals mainly relies on SCs, which are adult muscle-resident stem cells that are 

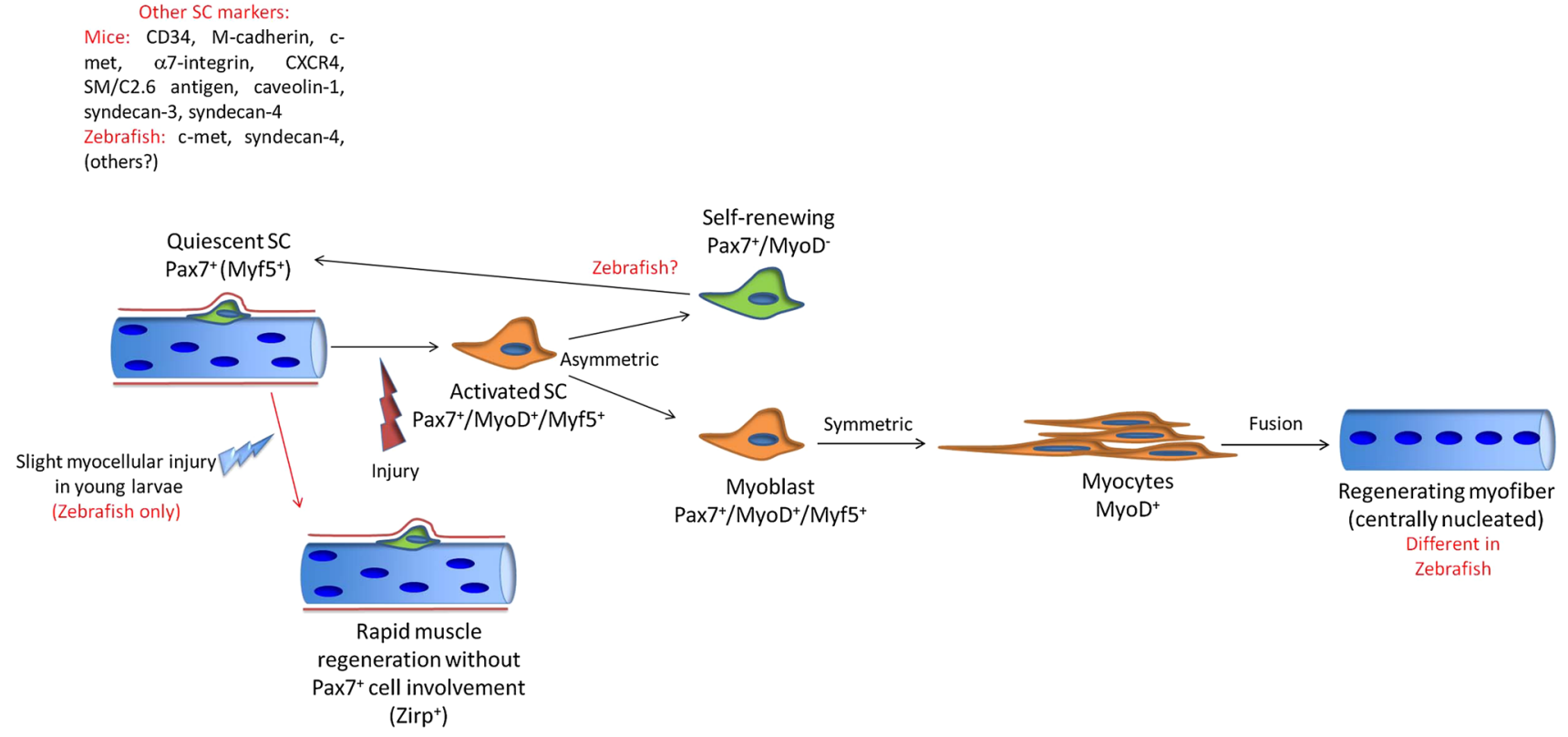

Fig. 5 Comparative scheme of regenerative myogenesis in mammals and teleosts. Red highlights the main differences

responsible not only for post-natal muscle growth but also for muscle regeneration after damage. These cells were first identified in 1961 by Mauro [114], who named them for their 'satellite' position with respect to the myofiber. Indeed, starting from E16.5 in mouse, SCs can be easily identified using electron microscopy as mononucleated cells positioned at the periphery of myofibers, between the basal lamina and the sarcolemma (Fig. 5).

During the first 3-4 weeks of post-natal life in mouse, juvenile and actively proliferating SCs are responsible for perinatal muscle growth, while successively, once the adult has reached a fixed body size, their SCs remain in a G0 phase until they are correctly stimulated [68]. Muscle and body size can be further regulated by the modulation of specific signaling pathways, such as overexpression of the insulin-like growth factors [115] or repression of Myostatin (GDF-8), a TGF- $\beta$ family member, which is a well-known myogenesis inhibitor [116].

Although the adult SC population accounts for less than $5 \%$ of the total number of nuclei, when there is muscle damage, these cells can re-enter the cell cycle, and rapidly proliferate and differentiate into new fibers. This property explains the ability of skeletal muscle to extensively regenerate, even if the mammalian myonuclei are post-mitotic [117, 118].

To maintain a quiescent pool of SCs through multiple regenerative cycles, SCs have been shown to undergo asymmetric cell division, which gives rise to one daughter cell destined to self-renew and another committed to differentiation [119-123]. According to the 'immortal DNA strand hypothesis' [124], the occurrence of asymmetric divisions ensures the co-segregation of both parental DNA strands into the self-renewing daughter cell (a process that is also referred to as 'template DNA strand segregation'). This process therefore avoids the accumulation of mutations during replication in the stem cell population. In vivo self-renewal of SCs has been demonstrated by transplantation experiments. Due to the difficulties in obtaining a pure, still quiescent population of dissociated single SCs, self-renewal was initially demonstrated by transplantation of an entire myofiber in irradiated mice [125]. The more recent advances in SC isolation techniques have provided verification of in vivo self-renewal from single transplanted SCs [126], and have demonstrated that SCs retain stem cell function over multiple rounds of serial transplantation [127]. SCs actually represent a heterogeneous population in terms of their developmental origin, and they show expression of different markers, and have different growth factor requirements, structural gene expression upon differentiation, and stemness properties [128].

\section{Satellite cell origin and markers}

The SCs of the limb and back muscles share a common somitic origin [129-131], while the SCs in the head muscles derive from prechordal and cranial paraxial mesoderm [132]. This suggests that SCs reflect the different embryonic origins of the muscle in which they reside. Due to the greater number of studies of the limb musculature, this review will mainly focus on post-natal myogenesis of SCs in the limb muscles.

Adult muscle progenitors in the limbs originate from multipotent cells in the dermomyotome that express Pax3 
and Pax7. This population represents a reservoir of muscleresident progenitor cells that continue to proliferate during embryonic and fetal development, where they contribute to muscle development, and then adopt the SC positioning during post-natal life $[43,53]$. Recently, it was demonstrated that SC progenitors are also primed by Myf5 [133], Mrf4 [134], and MyoD [135, 136] during prenatal phases. During adulthood, Pax 3 expression is restricted to distinct muscles. In particular, there are Pax3-positive SCs in the diaphragm and in some forelimb muscles, while they are almost absent in the hindlimbs [137]. In contrast, Pax7 is expressed in all quiescent SCs and activated myoblasts, and it represents the main marker of SC populations. Indeed, high levels of Pax7 expression have been shown to mark the quiescent or 'stem' state of SCs [120, 127, 138]. Pax7 has been shown to be necessary for maintenance of SCs during perinatal and juvenile life. Indeed, Pax7-null mice have skeletal muscle deficiency at birth, which suggests a unique requirement for Pax7 in myogenic SC function. In these mice, SCs are present at birth and can differentiate into skeletal muscle, but they are progressively lost during post-natal development [52, 137, 139, 140]. In 2009, Lepper et al. [141] used tamoxifen-induced Pax7 inactivation to demonstrate that, when $\operatorname{Pax} 7$ is inactivated in adult mice, SC function is not compromised, and regeneration occurs correctly. Very recently, however, their study was reinterpreted, as it has been demonstrated that continuous tamoxifen administration with chow results in sustained $\operatorname{Pax} 7$ deletion that finally leads to defective muscle regeneration, due to cell-cycle arrest and precocious differentiation [142, 143], therefore also underlining the main role for Pax7 in adult SCs.

Other well-known SC markers include CD34 [144], M-cadherin [145, 146], c-met [145], $\alpha 7$-integrin [147, 148], CXCR4 [149], SM/C2.6 antigen [150], Caveolin-1 [147, 151], and Syndecan-3 and Syndecan-4 [152, 153].

As myonuclei are post-mitotic, muscle regeneration after damage relies completely on SC activation, proliferation, withdrawal from cell cycle, terminal differentiation, and fusion together (for de novo myotube formation) or with damaged myofibers (to replace lost myonuclei). These processes partially parallel developmental myogenesis, in which fusion of mononucleated muscle progenitors gives rise to multinucleated muscle fibers. Similarly to what happens during prenatal muscle development, post-natal myogenesis that is driven by SCs follows a precise regulatory factor hierarchy, with the MRFs acting downstream of the Pax genes.

\section{Initial steps of muscle regeneration: inflammatory phase and satellite cell activation}

Adult, Pax7-positive SCs are quiescent and in G0 during homeostasis, with the Myf5 locus already active in many quiescent SCs [144, 154]. Myf5 is considered to be the first marker of myogenic commitment, and, therefore, to justify the positivity of some quiescent SCs for Myf5, it has been proposed that many SCs become quiescent after committing to skeletal muscle lineage [122]. According to this theory, the population that is negative for Myf5 would represent the stem cell compartment that is destined for self-renewal. To explain how SCs can maintain quiescence while already being primed for differentiation, it has recently been proposed that Myf5 mRNA in quiescent cells is sequestered in mRNP granules, and only released upon activation [155]. As further support for this, it has also been proposed that Myf5 protein levels regulate muscle stem cell fate by regulating the balance between commitment and self-renewal [156].

As a consequence of muscle injury or in chronic diseases, skeletal muscle can degenerate, and the following regeneration process can be divided into three different phases: inflammation, tissue reconstruction, and tissue remodeling. Inflammation occurs after plasma membrane disruption and the consequent chemotactic recruitment of inflammatory cells. The first inflammatory wave is mainly composed of neutrophils, then a major role is played by macrophages, initially with phagocytosis of the cellular debris in the necrotic area, and then through sustaining SC proliferation and differentiation [157]. Already during the initial inflammatory phase, SCs are activated to successively undergo rapid proliferation, followed by differentiation and fusion with existing myofibers or with other myoblasts. During the proliferative phase of muscle reconstruction, newly activated SCs re-enter the cell cycle, start to proliferate, and co-express $\mathrm{Pax} 7$ and $\mathrm{MyoD}$, which is the hallmark of the activated state [138, 158, 159]. Interestingly, while most SCs undergo proliferation and downregulate Pax7 before differentiation, some retain Pax7 expression, down-regulate $\mathrm{MyoD}$, and return to quiescence $[138,159]$. MyoD also appears to have a role in the regulation of the balance between self-renewal and differentiation, as $\mathrm{Myod}^{-/-}$adult mice have increased numbers of SCs and myoblasts [160, 161]. Myf5 also has a role during differentiation, whereby $M y f 5$-null mice are characterized by delayed regeneration, with the formation of hypertrophic myofibers and the persistence of fibrosis [156].

\section{Satellite cell differentiation and tissue remodeling}

After proliferation and migration through the damaged area, early SC differentiation leads to the expression of Mrf4 and Myogenin, along with transcription factors of the MEF2 family. Both Mrf4 and Myogenin are only expressed during differentiation $[159,162,163]$, and they appear not to be necessary for adult muscle progenitors [164-166]. Terminal differentiation is marked by the expression of sarcomeric and sarcoplasmic proteins and by fusion into 
multinucleated myotubes. During regeneration, typical developmental markers are re-expressed, such as embryonic and neonatal MyHC $[125,167,168]$. The expression of these MyHC isoforms in adult mice is considered to be a marker of ongoing regeneration. SC differentiation is followed by fusion and maturation of the regenerating myofibers, which are initially characterized by a reduced crosssectional area and by the presence of centrally located myonuclei. The extent of tissue remodeling depends on the extent of damage and on the involvement of the basal lamina. Maturation and tissue remodeling require the re-establishment of the neuromuscular junctions and the expression of adult MyHC isoforms, as the initially fast and then also the slow $[169,170]$. In adult mice, the entire process of muscle regeneration upon acute injury is completed within 3-4 weeks [68].

\section{Aged satellite cells and unorthodox myogenic populations}

With age, the number of SCs in skeletal muscle progressively decreases [171, 172]. Intriguingly, however, the intrinsic regeneration potential is maintained through time, as demonstrated by the successful regeneration that has been obtained after grafts of old muscle cells into young hosts [173, 174], and by parabiosis experiments where young and old SCs share the same microenvironment [175]. This evidence strongly suggests that the niche microenvironment has a central role in determining the SC potential.

As well as SCs, other unorthodox myogenic populations have been identified that can generate skeletal muscle both in vivo and in vitro [148, 176-183]. However, recent studies using inducible genetic strategies to ablate adult $\mathrm{Pax} 7^{+}$ SCs have demonstrated that, in the absence of SCs, skeletal muscle repair after damage is not successful, thus demonstrating that the in vivo contribution of these alternative cell types is secondary to the major role of the SCs [184-187].

Post-embryonic myogenesis and regeneration in zebrafish

\section{Post-larval muscle growth}

At variance with mammals, where muscle and body growth are determined and finalized according to a fixed body size, many fish show indeterminate growth through both hyperplasia and hypertrophy mechanisms in response to multiple factors, thus providing continuous growth throughout their entire life [188]. Interestingly, however, muscle growth in zebrafish is determinate, with very little muscle fiber hyperplasia after the juvenile phase, even when subjected to growth hormone treatment [189]. Similar to mammals [116, 190], in zebrafish, inhibition of Myostatin leads to enhanced hyperplasia and, in some cases, hypertrophy, and consequently to increased body size [191-193]. This evidence highlights a conserved role for Myostatin in the regulation of muscle growth. However, while expression of Myostatin in mice is mainly confined to skeletal muscle, in fish, Myostatin is expressed in a variety of other tissues [194, 195], which suggests possible nonconserved roles between mammals and teleosts.

\section{Muscle regeneration properties and first satellite cell identification}

In past years, it was generally believed that zebrafish larvae can regenerate muscle tissue through a de-differentiation process, similar to that of many amphibians. However, a recent study has shed particular light on this aspect, with the confirmation of the absence of epimorphic skeletal muscle regeneration in zebrafish larvae [196]. Thus, it is now, in contrast, universally accepted that teleosts can generate and regenerate muscle from a population of 'satellite-like' myogenic precursor cells. As in mammals, in zebrafish, mitotically inactive $\mathrm{Pax}^{+}$cells that originate from the dermomyotome can be identified beneath the basal lamina of the myofiber throughout the larval, juvenile, and adult stages [90, 197]. Their quiescent state, position, expression of Pax7, and permanence in the adult stages have suggested that they represent a resident progenitor cell population similar to mammalian SCs. Moreover, these $\mathrm{Pax} 7^{+}$cells in zebrafish also express other typical SC markers, such as the HGF receptor c-met [90] and Syndecan-4 [198].

However, evidence for rapid recovery from slight myocellular injury within the zebrafish embryo without the involvement of cell proliferation has recently been reported. These events have been associated with positivity for Xirp (Xin-actin-binding repeat-containing protein) in the damaged area [199], which represents a unique feature with respect to mammals. Interestingly, however, the Xin proteins have also been associated with muscle regeneration in mice [200].

The regenerative ability of zebrafish muscles upon acute injury and in chronic pathologies has also been characterized [197, 201]. In particular, the recent generation of a pax7a-reporter zebrafish line allowed the behavior of Pax7expressing cells after cardiotoxin injury and in dystrophic models to be follow precisely [197]. Similar to mammals, muscle injury in teleosts results in muscle progenitor cell migration to the site of injury and proliferation, as evident from the marked increase in BrdU incorporation at the early stages following muscle damage, along with the degeneration and necrosis of the damaged muscle fibers. At the same time, expression of the MRFs is strongly upregulated in myofibers near the site of injury, in order to sustain the process of regeneration [197, 201]. As in mammals, damaged tissue is temporarily substituted by connective tissue, and then finally newly formed myofibers are 
identifiable due to their small diameter [197, 201]. One of the most curious differences during regeneration is that, at variance with mice, in which one of the main hallmarks of ongoing regeneration is the presence of centrally nucleated myofibers, central nuclei are only rarely observed during muscle regeneration in teleosts [201]. Intriguingly, regenerating dystrophic zebrafish larvae show reduced levels of central nucleation when compared to wild-type siblings [202], which again shows a strong difference with what happens in mammals, probably due to the different mechanisms that characterize muscle growth in these two models. A comparative model for zebrafish and mammal muscle regeneration is illustrated in Fig. 5.

\section{Concluding remarks}

In the last few decades, zebrafish have emerged as a useful and interesting model for studies on different biological processes that have been widely discussed for higher vertebrates. During this time, it has been demonstrated that a number of developmental events described for mammals are only partially conserved in teleosts. The existence of myogenic progenitors, such as the adaxial cells, the differentiation of a functional myotome before the end of somitogenesis, and the different timing and requirements of the MRFs, clearly demonstrate that direct comparisons between teleosts and mammals are not always possible. Conversely, common features between mammals and teleosts have been extensively demonstrated, such as the source of myogenic progenitors, the molecules involved in myogenic commitment, and the regulation of fiber type diversification.

The possible evolutionary origins of the differences in myogenesis between mammals and teleosts require much more detailed consideration than that behind the scope of the present review. Overall, the existence of common and divergent aspects between myogenesis in mammals and teleosts should be firmly considered during any direct, and potentially forced, parallels between what occurs in teleosts and in mammals. For the muscle regeneration processes, the evidence obtained to date remains too preliminary and not always conserved enough for strong conclusions to be drawn, thus leaving many questions still open that need to be addressed in the future.

Acknowledgments This study was supported by ERC StG2011 (RegeneratioNfix 280611) and the Italian Ministry of University and Research (MIUR-Futuro in Ricerca 2010). We apologize to authors who have not been cited directly because of space limitations.

Open Access This article is distributed under the terms of the Creative Commons Attribution License which permits any use, distribution, and reproduction in any medium, provided the original author(s) and the source are credited.

\section{References}

1. Wilting J, Brand-Saberi B, Huang R, Zhi Q, Kontges G, Ordahl CP, Christ B (1995) Angiogenic potential of the avian somite. Dev Dyn 202(2):165-171. doi:10.1002/aja.1002020208

2. Emery AE (2002) The muscular dystrophies. Lancet 359(9307):687-695

3. Christ B, Ordahl CP (1995) Early stages of chick somite development. Anat Embryol 191(5):381-396

4. Cinnamon Y, Kahane N, Bachelet I, Kalcheim C (2001) The sub-lip domain-a distinct pathway for myotome precursors that demonstrate rostral-caudal migration. Development 28(3):341-351

5. Rescan PY (2001) Regulation and functions of myogenic regulatory factors in lower vertebrates. Comp Biochem Physiol B 130(1):1-12

6. Barresi MJ, D'Angelo JA, Hernandez LP, Devoto SH (2001) Distinct mechanisms regulate slow-muscle development. Curr Biol 11(18):1432-1438

7. Devoto SH, Stoiber W, Hammond CL, Steinbacher P, Haslett JR, Barresi MJ, Patterson SE, Adiarte EG, Hughes SM (2006) Generality of vertebrate developmental patterns: evidence for a dermomyotome in fish. Evolut Dev 8(1):101-110. doi:10.1111/j.1525-142X.2006.05079.x

8. Devoto SH, Melancon E, Eisen JS, Westerfield M (1996) Identification of separate slow and fast muscle precursor cells in vivo, prior to somite formation. Development 122(11):3371-3380

9. Linker C, Lesbros C, Gros J, Burrus LW, Rawls A, Marcelle C (2005) beta-Catenin-dependent Wnt signalling controls the epithelial organisation of somites through the activation of paraxis. Development 13 (17):3895-3905. doi:10.1242/dev.01961

10. Cinnamon Y, Kahane N, Kalcheim C (1999) Characterization of the early development of specific hypaxial muscles from the ventrolateral myotome. Development 126(19):4305-4315

11. Gros J, Scaal M, Marcelle C (2004) A two-step mechanism for myotome formation in chick. Dev Cell 6(6):875-882. doi:10.1016/j.devcel.2004.05.006

12. Kahane N, Cinnamon Y, Bachelet I, Kalcheim C (2001) The third wave of myotome colonization by mitotically competent progenitors: regulating the balance between differentiation and proliferation during muscle development. Development 128(12):2187-2198

13. Kahane N, Cinnamon Y, Kalcheim C (1998) The origin and fate of pioneer myotomal cells in the avian embryo. Mech Dev 74(1-2):59-73

14. Kahane N, Cinnamon Y, Kalcheim C (2002) The roles of cell migration and myofiber intercalation in patterning formation of the postmitotic myotome. Development 129(11):2675-2687

15. Kahane N, Kalcheim C (1998) Identification of early postmitotic cells in distinct embryonic sites and their possible roles in morphogenesis. Cell Tissue Res 294(2):297-307

16. Ordahl CP, Berdougo E, Venters SJ, Denetclaw WF Jr (2001) The dermomyotome dorsomedial lip drives growth and morphogenesis of both the primary myotome and dermomyotome epithelium. Development 128(10):1731-1744

17. Venters SJ, Ordahl CP (2002) Persistent myogenic capacity of the dermomyotome dorsomedial lip and restriction of myogenic competence. Development 129(16):3873-3885

18. Tajbakhsh S, Rocancourt D, Buckingham M (1996) Muscle progenitor cells failing to respond to positional cues adopt 
non-myogenic fates in myf-5 null mice. Nature 384(6606):266270. doi:10.1038/384266a0

19. Cossu G, De Angelis L, Borello U, Berarducci B, Buffa V, Sonnino C, Coletta M, Vivarelli E, Bouche M, Lattanzi L, Tosoni D, Di Donna S, Berghella L, Salvatori G, Murphy P, Cusella-De Angelis MG, Molinaro M (2000) Determination, diversification and multipotency of mammalian myogenic cells. Int J Dev Biol 44(6):699-706

20. Cossu G, Borello U (1999) Wnt signaling and the activation of myogenesis in mammals. EMBO J 18(24):6867-6872. doi:10.1 093/emboj/18.24.6867

21. Kablar B, Krastel K, Ying C, Asakura A, Tapscott SJ, Rudnicki MA (1997) MyoD and Myf-5 differentially regulate the development of limb versus trunk skeletal muscle. Development 124(23):4729-4738

22. Rudnicki MA, Braun T, Hinuma S, Jaenisch R (1992) Inactivation of MyoD in mice leads to up-regulation of the myogenic HLH gene Myf-5 and results in apparently normal muscle development. Cell 71(3):383-390

23. Burke AC, Nowicki JL (2003) A new view of patterning domains in the vertebrate mesoderm. Dev Cell 4(2):159-165

24. Braun T, Rudnicki MA, Arnold HH, Jaenisch R (1992) Targeted inactivation of the muscle regulatory gene Myf-5 results in abnormal rib development and perinatal death. Cell 71(3):369-382

25. Rudnicki MA, Schnegelsberg PN, Stead RH, Braun T, Arnold HH, Jaenisch R (1993) MyoD or Myf-5 is required for the formation of skeletal muscle. Cell 75(7):1351-1359

26. Kassar-Duchossoy L, Gayraud-Morel B, Gomes D, Rocancourt D, Buckingham M, Shinin V, Tajbakhsh S (2004) Mrf4 determines skeletal muscle identity in Myf5:Myod double-mutant mice. Nature 431(7007):466-471

27. Hinterberger TJ, Sassoon DA, Rhodes SJ, Konieczny SF (1991) Expression of the muscle regulatory factor MRF4 during somite and skeletal myofiber development. Dev Biol 147(1):144-156

28. Hasty P, Bradley A, Morris JH, Edmondson DG, Venuti JM, Olson EN, Klein WH (1993) Muscle deficiency and neonatal death in mice with a targeted mutation in the myogenin gene. Nature 364(6437):501-506. doi:10.1038/364501a0

29. Nabeshima Y, Hanaoka K, Hayasaka M, Esumi E, Li S, Nonaka I, Nabeshima Y (1993) Myogenin gene disruption results in perinatal lethality because of severe muscle defect. Nature 364(6437):532-535. doi:10.1038/364532a0

30. Rawls A, Valdez MR, Zhang W, Richardson J, Klein WH, Olson EN (1998) Overlapping functions of the myogenic bHLH genes MRF4 and MyoD revealed in double mutant mice. Development 125(13):2349-2358

31. Bentzinger CF, Wang YX, Rudnicki MA (2012) Building muscle: molecular regulation of myogenesis. Cold Spring Harbor Perspect Biol 4(2). doi:10.1101/cshperspect.a008342

32. Gurdon JB, Dyson S, St Johnston D (1998) Cells' perception of position in a concentration gradient. Cell 95(2):159-162

33. Parr BA, Shea MJ, Vassileva G, McMahon AP (1993) Mouse Wnt genes exhibit discrete domains of expression in the early embryonic CNS and limb buds. Development 119(1):247-261

34. Borycki AG, Mendham L, Emerson CP Jr (1998) Control of somite patterning by Sonic hedgehog and its downstream signal response genes. Development 125(4):777-790

35. Borello U, Berarducci B, Murphy P, Bajard L, Buffa V, Piccolo S, Buckingham M, Cossu G (2006) The Wnt/beta-catenin pathway regulates Gli-mediated Myf5 expression during somitogenesis. Development 133(18):3723-3732. doi:10.1242/dev.02517

36. Johnson RL, Laufer E, Riddle RD, Tabin C (1994) Ectopic expression of Sonic hedgehog alters dorsal-ventral patterning of somites. Cell 79(7):1165-1173
37. Pourquie O, Coltey M, Breant C, Le Douarin NM (1995) Control of somite patterning by signals from the lateral plate. Proc Natl Acad Sci USA 92(8):3219-3223

38. Bray SJ (2006) Notch signalling: a simple pathway becomes complex. Nat Rev 7(9):678-689. doi:10.1038/nrm2009

39. Jarriault S, Brou C, Logeat F, Schroeter EH, Kopan R, Israel A (1995) Signalling downstream of activated mammalian Notch. Nature 377(6547):355-358. doi:10.1038/377355a0

40. Kuroda K, Tani S, Tamura K, Minoguchi S, Kurooka H, Honjo T (1999) Delta-induced Notch signaling mediated by RBP-J inhibits MyoD expression and myogenesis. J Biol Chem 274(11):7238-7244

41. Schuster-Gossler K, Cordes R, Gossler A (2007) Premature myogenic differentiation and depletion of progenitor cells cause severe muscle hypotrophy in Delta1 mutants. Proc Natl Acad Sci USA 104(2):537-542. doi:10.1073/pnas.0608281104

42. Noll M (1993) Evolution and role of Pax genes. Curr Opin Genet Dev 3(4):595-605

43. Kassar-Duchossoy L, Giacone E, Gayraud-Morel B, Jory A, Gomes D, Tajbakhsh S (2005) Pax3/Pax7 mark a novel population of primitive myogenic cells during development. Genes Dev 19(12):1426-1431. doi:10.1101/gad.345505

44. Grifone R, Demignon J, Houbron C, Souil E, Niro C, Seller MJ, Hamard G, Maire P (2005) Six 1 and Six4 homeoproteins are required for Pax3 and Mrf expression during myogenesis in the mouse embryo. Development 132(9):2235-2249. doi: $10.1242 /$ dev.01773

45. Grifone R, Demignon J, Giordani J, Niro C, Souil E, Bertin F, Laclef C, Xu PX, Maire P (2007) Eya1 and Eya2 proteins are required for hypaxial somitic myogenesis in the mouse embryo. Dev Biol 302(2):602-616. doi:10.1016/j.ydbio.2006.08.059

46. Marcelle C, Wolf J, Bronner-Fraser M (1995) The in vivo expression of the FGF receptor FREK mRNA in avian myoblasts suggests a role in muscle growth and differentiation. Dev Biol 172(1):100-114. doi:10.1006/dbio. 1995.0008

47. Epstein JA, Shapiro DN, Cheng J, Lam PY, Maas RL (1996) Pax3 modulates expression of the c-Met receptor during limb muscle development. Proc Natl Acad Sci USA 93(9):4213-4218

48. Bober E, Franz T, Arnold HH, Gruss P, Tremblay P (1994) Pax-3 is required for the development of limb muscles: a possible role for the migration of dermomyotomal muscle progenitor cells. Development 120(3):603-612

49. Tremblay P, Dietrich S, Mericskay M, Schubert FR, Li Z, Paulin D (1998) A crucial role for Pax3 in the development of the hypaxial musculature and the long-range migration of muscle precursors. Dev Biol 203(1):49-61. doi:10.1006/d bio. 1998.9041

50. Daston G, Lamar E, Olivier M, Goulding M (1996) Pax-3 is necessary for migration but not differentiation of limb muscle precursors in the mouse. Development 122(3):1017-1027

51. Tajbakhsh S, Rocancourt D, Cossu G, Buckingham M (1997) Redefining the genetic hierarchies controlling skeletal myogenesis: Pax-3 and Myf-5 act upstream of MyoD. Cell 89(1): $127-138$

52. Seale P, Sabourin LA, Girgis-Gabardo A, Mansouri A, Gruss P, Rudnicki MA (2000) Pax7 is required for the specification of myogenic satellite cells. Cell 102(6):777-786

53. Relaix F, Rocancourt D, Mansouri A, Buckingham M (2005) A Pax3/Pax7-dependent population of skeletal muscle progenitor cells. Nature 435(7044):948-953. doi:10.1038/nature03594

54. Relaix F, Rocancourt D, Mansouri A, Buckingham M (2004) Divergent functions of murine Pax3 and Pax7 in limb muscle development. Genes Dev 18(9):1088-1105. doi:10.1101/ gad.301004

55. Hutcheson DA, Zhao J, Merrell A, Haldar M, Kardon G (2009) Embryonic and fetal limb myogenic cells are derived from 
developmentally distinct progenitors and have different requirements for beta-catenin. Genes Dev 23(8):997-1013

56. Noden DM, Francis-West P (2006) The differentiation and morphogenesis of craniofacial muscles. Dev Dyn 235(5):11941218. doi: $10.1002 /$ dvdy. 20697

57. Sambasivan R, Kuratani S, Tajbakhsh S (2011) An eye on the head: the development and evolution of craniofacial muscles. Development 138(12):2401-2415. doi:10.1242/dev.040972

58. Rios AC, Marcelle C (2009) Head muscles: aliens who came in from the cold? Dev Cell 16(6):779-780. doi:10.1016/j.devcel.2009.06.004

59. Mootoosamy RC, Dietrich S (2002) Distinct regulatory cascades for head and trunk myogenesis. Development 129(3):573-583

60. Tzahor E, Kempf H, Mootoosamy RC, Poon AC, Abzhanov A, Tabin CJ, Dietrich S, Lassar AB (2003) Antagonists of Wnt and BMP signaling promote the formation of vertebrate head muscle. Genes Dev 17(24):3087-3099. doi:10.1101/gad.1154103

61. Dong F, Sun X, Liu W, Ai D, Klysik E, Lu MF, Hadley J, Antoni L, Chen L, Baldini A, Francis-West P, Martin JF (2006) Pitx2 promotes development of splanchnic mesoderm-derived branchiomeric muscle. Development 133(24):4891-4899. doi:10.1242/dev.02693

62. Shih HP, Gross MK, Kioussi C (2007) Cranial muscle defects of Pitx2 mutants result from specification defects in the first branchial arch. Proc Natl Acad Sci USA 104(14):5907-5912. doi:10.1073/pnas.0701122104

63. Dastjerdi A, Robson L, Walker R, Hadley J, Zhang Z, Rodriguez-Niedenfuhr M, Ataliotis P, Baldini A, Scambler P, FrancisWest $P$ (2007) Tbx1 regulation of myogenic differentiation in the limb and cranial mesoderm. Dev Dyn 236(2):353-363. doi: 10.1002/dvdy. 21010

64. Sambasivan R, Gayraud-Morel B, Dumas G, Cimper C, Paisant S, Kelly RG, Tajbakhsh S (2009) Distinct regulatory cascades govern extraocular and pharyngeal arch muscle progenitor cell fates. Dev Cell 16(6):810-821. doi:10.1016/j.devcel.2009.05.008

65. Theis S, Patel K, Valasek P, Otto A, Pu Q, Harel I, Tzahor E, Tajbakhsh S, Christ B, Huang R (2010) The occipital lateral plate mesoderm is a novel source for vertebrate neck musculature. Development 137(17):2961-2971. doi:10.1242/ dev.049726

66. Biressi S, Molinaro M, Cossu G (2007) Cellular heterogeneity during vertebrate skeletal muscle development. Dev Biol 308(2):281-293

67. Biressi S, Tagliafico E, Lamorte G, Monteverde S, Tenedini E, Roncaglia E, Ferrari S, Ferrari S, Cusella-De Angelis MG, Tajbakhsh S, Cossu G (2007) Intrinsic phenotypic diversity of embryonic and fetal myoblasts is revealed by genomewide gene expression analysis on purified cells. Dev Biol 304(2):633-651

68. Tajbakhsh S (2009) Skeletal muscle stem cells in developmental versus regenerative myogenesis. J Intern Med 266(4):372-389

69. Stockdale FE (1992) Myogenic cell lineages. Dev Biol 154(2):284-298

70. Gunning P, Hardeman E (1991) Multiple mechanisms regulate muscle fiber diversity. FASEB J 5(15):3064-3070

71. Schiaffino S, Reggiani C (1996) Molecular diversity of myofibrillar proteins: gene regulation and functional significance. Physiol Rev 76(2):371-423

72. Wigmore PM, Evans DJ (2002) Molecular and cellular mechanisms involved in the generation of fiber diversity during myogenesis. Int Rev Cytol 216:175-232

73. Messina G, Biressi S, Monteverde S, Magli A, Cassano M, Perani L, Roncaglia E, Tagliafico E, Starnes L, Campbell CE, Grossi M, Goldhamer DJ, Gronostajski RM, Cossu G (2010)
Nfix regulates fetal-specific transcription in developing skeletal muscle. Cell 140(4):554-566. doi:10.1016/j.cell.2010.01.027

74. Gronostajski RM (2000) Roles of the NFI/CTF gene family in transcription and development. Gene 249(1-2):31-45

75. Mourikis P, Gopalakrishnan S, Sambasivan R, Tajbakhsh S (2012) Cell-autonomous Notch activity maintains the temporal specification potential of skeletal muscle stem cells. Development 139(24):4536-4548. doi:10.1242/dev.084756

76. Schiaffino S (2010) Fibre types in skeletal muscle: a personal account. Acta Physiol (Oxf) 199(4):451-463. doi:10.1111/j.1748-1716.2010.02130.x

77. Calabria E, Ciciliot S, Moretti I, Garcia M, Picard A, Dyar KA, Pallafacchina G, Tothova J, Schiaffino S, Murgia M (2009) NFAT isoforms control activity-dependent muscle fiber type specification. Proc Natl Acad Sci USA 106(32):13335-13340

78. Hagiwara N (2011) Sox6, jack of all trades: a versatile regulatory protein in vertebrate development. Dev Dyn 240(6):13111321. doi:10.1002/dvdy.22639

79. Hagiwara N, Yeh M, Liu A (2007) Sox6 is required for normal fiber type differentiation of fetal skeletal muscle in mice. Dev Dyn 236(8):2062-2076. doi:10.1002/dvdy.21223

80. An CI, Dong Y, Hagiwara N (2011) Genome-wide mapping of Sox6 binding sites in skeletal muscle reveals both direct and indirect regulation of muscle terminal differentiation by Sox6. BMC Dev Biol 11:59. doi:10.1186/1471-213X-11-59

81. van Rooij E, Quiat D, Johnson BA, Sutherland LB, Qi X, Richardson JA, Kelm RJ Jr, Olson EN (2009) A family of microRNAs encoded by myosin genes governs myosin expression and muscle performance. Dev Cell 17(5):662-673. doi:10.1016/j.devcel.2009.10.013

82. Quiat D, Voelker KA, Pei J, Grishin NV, Grange RW, BasselDuby R, Olson EN (2011) Concerted regulation of myofiberspecific gene expression and muscle performance by the transcriptional repressor Sox6. Proc Natl Acad Sci USA 108(25):10196-10201. doi:10.1073/pnas.1107413108

83. Niro C, Demignon J, Vincent S, Liu Y, Giordani J, Sgarioto N, Favier M, Guillet-Deniau I, Blais A, Maire P (2010) Six1 and Six4 gene expression is necessary to activate the fast-type muscle gene program in the mouse primary myotome. Dev Biol 338(2):168-182. doi:10.1016/j.ydbio.2009.11.031

84. Kimmel CB, Ballard WW, Kimmel SR, Ullmann B, Schilling TF (1995) Stages of embryonic development of the zebrafish. Dev Dyn 203(3):253-310. doi:10.1002/aja.1002030302

85. Stickney HL, Barresi MJ, Devoto SH (2000) Somite development in zebrafish. Dev Dyn 219(3):287-303. doi:10.1002/10970177(2000)9999:9999<::AID-DVDY1065>3.0.CO;2-A

86. Stellabotte F, Dobbs-McAuliffe B, Fernandez DA, Feng X, Devoto SH (2007) Dynamic somite cell rearrangements lead to distinct waves of myotome growth. Development 134(7):12531257. doi: $10.1242 /$ dev. 000067

87. Henry CA, Amacher SL (2004) Zebrafish slow muscle cell migration induces a wave of fast muscle morphogenesis. Dev Cell 7(6):917-923. doi:10.1016/j.devcel.2004.09.017

88. Blagden CS, Currie PD, Ingham PW, Hughes SM (1997) Notochord induction of zebrafish slow muscle mediated by Sonic hedgehog. Genes Dev 11(17):2163-2175

89. Elworthy S, Hargrave M, Knight R, Mebus K, Ingham PW (2008) Expression of multiple slow myosin heavy chain genes reveals a diversity of zebrafish slow twitch muscle fibres with differing requirements for Hedgehog and Prdm1 activity. Development 135(12):2115-2126. doi:10.1242/dev.015719

90. Hollway GE, Bryson-Richardson RJ, Berger S, Cole NJ, Hall TE, Currie PD (2007) Whole-somite rotation generates muscle progenitor cell compartments in the developing zebrafish embryo. Dev Cell 12(2):207-219. doi:10.1016/j.devcel.2007.01.001 
91. Stellabotte F, Devoto SH (2007) The teleost dermomyotome. Dev Dyn 236(9):2432-2443. doi:10.1002/dvdy.21253

92. Hammond CL, Hinits Y, Osborn DP, Minchin JE, Tettamanti G, Hughes SM (2007) Signals and myogenic regulatory factors restrict pax3 and pax7 expression to dermomyotome-like tissue in zebrafish. Dev Biol 302(2):504-521. doi:10.1016/j.ydbio.2006.10.009

93. Groves JA, Hammond CL, Hughes SM (2005) Fgf8 drives myogenic progression of a novel lateral fast muscle fibre population in zebrafish. Development 132(19):4211-4222. doi:10.1242/dev.01958

94. Maves L, Waskiewicz AJ, Paul B, Cao Y, Tyler A, Moens CB, Tapscott SJ (2007) Pbx homeodomain proteins direct Myod activity to promote fast-muscle differentiation. Development 134(18):3371-3382. doi:10.1242/dev.003905

95. Hinits Y, Osborn DP, Hughes SM (2009) Differential requirements for myogenic regulatory factors distinguish medial and lateral somitic, cranial and fin muscle fibre populations. Development 136(3):403-414. doi:10.1242/dev.028019

96. Hinits Y, Osborn DP, Carvajal JJ, Rigby PW, Hughes SM (2007) Mrf4 (myf6) is dynamically expressed in differentiated zebrafish skeletal muscle. Gene Expr Patterns 7(7):738-745. doi:10.1016/j.modgep.2007.06.003

97. Schnapp E, Pistocchi AS, Karampetsou E, Foglia E, Lamia CL, Cotelli F, Cossu G (2009) Induced early expression of mrf4 but not myog rescues myogenesis in the myod/myf5 double-morphant zebrafish embryo. J Cell Sci 122(Pt 4):481-488. doi:10.1 242/jcs.038356

98. Hinits Y, Williams VC, Sweetman D, Donn TM, Ma TP, Moens CB, Hughes SM (2011) Defective cranial skeletal development, larval lethality and haploinsufficiency in Myod mutant zebrafish. Dev Biol 358(1):102-112. doi:10.1016/j.ydbio.2011.07.015

99. Hernandez LP, Patterson SE, Devoto SH (2005) The development of muscle fiber type identity in zebrafish cranial muscles. Anat Embryol 209(4):323-334. doi:10.1007/ s00429-004-0448-4

100. Lin CY, Chen WT, Lee HC, Yang PH, Yang HJ, Tsai HJ (2009) The transcription factor Sixla plays an essential role in the craniofacial myogenesis of zebrafish. Dev Biol 331(2):152166. doi:10.1016/j.ydbio.2009.04.029

101. Lewis KE, Currie PD, Roy S, Schauerte H, Haffter P, Ingham PW (1999) Control of muscle cell-type specification in the zebrafish embryo by Hedgehog signalling. Dev Biol 216(2):469-480. doi:10.1006/dbio.1999.9519

102. Barresi MJ, Stickney HL, Devoto SH (2000) The zebrafish slow-muscle-omitted gene product is required for Hedgehog signal transduction and the development of slow muscle identity. Development 127(10):2189-2199

103. Feng X, Adiarte EG, Devoto SH (2006) Hedgehog acts directly on the zebrafish dermomyotome to promote myogenic differentiation. Dev Biol 300(2):736-746. doi:10.1016/j.ydbio.2006.08.056

104. Du SJ, Devoto SH, Westerfield M, Moon RT (1997) Positive and negative regulation of muscle cell identity by members of the hedgehog and TGF-beta gene families. J Cell Biol 139(1):145-156

105. Patterson SE, Bird NC, Devoto SH (2010) BMP regulation of myogenesis in zebrafish. Dev Dyn 239(3):806-817. doi:10.100 2/dvdy. 22243

106. Jackson HE, Ingham PW (2013) Control of muscle fibretype diversity during embryonic development: the zebrafish paradigm. Mech Dev 130(9-10):447-457. doi:10.1016/j. mod.2013.06.001

107. von Hofsten J, Elworthy S, Gilchrist MJ, Smith JC, Wardle FC, Ingham PW (2008) Prdm1- and Sox6-mediated transcriptional repression specifies muscle fibre type in the zebrafish embryo. EMBO Rep 9(7):683-689. doi:10.1038/embor.2008.73

108. Wang X, Ono Y, Tan SC, Chai RJ, Parkin C, Ingham PW (2011) Prdm1a and miR-499 act sequentially to restrict Sox6 activity to the fast-twitch muscle lineage in the zebrafish embryo. Development 138(20):4399-4404. doi:10.1242/dev.070516

109. Bessarab DA, Chong SW, Srinivas BP, Korzh V (2008) Six 1a is required for the onset of fast muscle differentiation in zebrafish. Dev Biol 323(2):216-228. doi:10.1016/j.ydbio.2008.08.015

110. Yao Z, Farr GH 3rd, Tapscott SJ, Maves L (2013) Pbx and Prdm1a transcription factors differentially regulate subsets of the fast skeletal muscle program in zebrafish. Biol Open 2(6):546-555. doi:10.1242/bio.20133921

111. Roy S, Wolff C, Ingham PW (2001) The u-boot mutation identifies a Hedgehog-regulated myogenic switch for fiber-type diversification in the zebrafish embryo. Genes Dev 15(12):15631576. doi:10.1101/gad.195801

112. Vincent SD, Mayeuf A, Niro C, Saitou M, Buckingham M (2012) Non conservation of function for the evolutionarily conserved prdm1 protein in the control of the slow twitch myogenic program in the mouse embryo. Mol Biol Evol 29(10):31813191. doi: 10.1093/molbev/mss 125

113. Pistocchi A, Gaudenzi G, Foglia E, Monteverde S, MorenoFortuny A, Pianca A, Cossu G, Cotelli F, Messina G (2013) Conserved and divergent functions of Nfix in skeletal muscle development during vertebrate evolution. Development 140(7):1528-1536. doi:10.1242/dev.076315

114. Mauro A (1961) Satellite cell of skeletal muscle fibers. J Biophys Biochem Cytol 9:493-495

115. Coleman ME, DeMayo F, Yin KC, Lee HM, Geske R, Montgomery C, Schwartz RJ (1995) Myogenic vector expression of insulin-like growth factor I stimulates muscle cell differentiation and myofiber hypertrophy in transgenic mice. J Biol Chem 270(20):12109-12116

116. McPherron AC, Lawler AM, Lee SJ (1997) Regulation of skeletal muscle mass in mice by a new TGF-beta superfamily member. Nature 387(6628):83-90. doi:10.1038/387083a0

117. Hawke TJ, Garry DJ (2001) Myogenic satellite cells: physiology to molecular biology. J Appl Physiol 91(2):534-551

118. Zammit PS, Partridge TA, Yablonka-Reuveni Z (2006) The skeletal muscle satellite cell: the stem cell that came in from the cold. J Histochem Cytochem 54(11):1177-1191. doi:10.1369/jh c.6R6995.2006

119. Conboy MJ, Karasov AO, Rando TA (2007) High incidence of non-random template strand segregation and asymmetric fate determination in dividing stem cells and their progeny. PLoS Biol 5(5):e102. doi:10.1371/journal.pbio.0050102

120. Mourikis P, Sambasivan R, Castel D, Rocheteau P, Bizzarro V, Tajbakhsh S (2012) A critical requirement for notch signaling in maintenance of the quiescent skeletal muscle stem cell state. Stem Cells 30(2):243-252. doi:10.1002/stem.775

121. Shinin V, Gayraud-Morel B, Gomes D, Tajbakhsh S (2006) Asymmetric division and cosegregation of template DNA strands in adult muscle satellite cells. Nat Cell Biol 8(7):677687. doi:10.1038/ncb1425

122. Kuang S, Kuroda K, Le Grand F, Rudnicki MA (2007) Asymmetric self-renewal and commitment of satellite stem cells in muscle. Cell 129(5):999-1010. doi:10.1016/j.cell.2007.03.044

123. Conboy IM, Rando TA (2002) The regulation of Notch signaling controls satellite cell activation and cell fate determination in postnatal myogenesis. Dev Cell 3(3):397-409

124. Cairns J (1975) Mutation selection and the natural history of cancer. Nature 255(5505):197-200

125. Collins CA, Olsen I, Zammit PS, Heslop L, Petrie A, Partridge TA, Morgan JE (2005) Stem cell function, self-renewal, and 
behavioral heterogeneity of cells from the adult muscle satellite cell niche. Cell 122(2):289-301

126. Sacco A, Doyonnas R, Kraft P, Vitorovic S, Blau HM (2008) Self-renewal and expansion of single transplanted muscle stem cells. Nature 456(7221):502-506. doi:10.1038/nature07384

127. Rocheteau P, Gayraud-Morel B, Siegl-Cachedenier I, Blasco MA, Tajbakhsh S (2012) A subpopulation of adult skeletal muscle stem cells retains all template DNA strands after cell division. Cell 148(1-2):112-125. doi:10.1016/j.cell.2011.11.049

128. Biressi S, Rando TA (2010) Heterogeneity in the muscle satellite cell population. Semin Cell Dev Biol 21(8):845-854. doi:10.1016/j.semcdb.2010.09.003

129. Armand O, Boutineau AM, Mauger A, Pautou MP, Kieny M (1983) Origin of satellite cells in avian skeletal muscles. Arch Anat Microsc Morphol Exp 72(2):163-181

130. Gros J, Manceau M, Thome V, Marcelle C (2005) A common somitic origin for embryonic muscle progenitors and satellite cells. Nature 435(7044):954-958. doi:10.1038/nature03572

131. Schienda J, Engleka KA, Jun S, Hansen MS, Epstein JA, Tabin CJ, Kunkel LM, Kardon G (2006) Somitic origin of limb muscle satellite and side population cells. Proc Natl Acad Sci USA 103(4):945-950. doi:10.1073/pnas.0510164103

132. Harel I, Nathan E, Tirosh-Finkel L, Zigdon H, Guimaraes-Camboa N, Evans SM, Tzahor E (2009) Distinct origins and genetic programs of head muscle satellite cells. Dev Cell 16(6):822832. doi:10.1016/j.devcel.2009.05.007

133. Biressi S, Bjornson CR, Carlig PM, Nishijo K, Keller C, Rando TA (2013) Myf5 expression during fetal myogenesis defines the developmental progenitors of adult satellite cells. Dev Biol 379(2):195-207. doi:10.1016/j.ydbio.2013.04.021

134. Sambasivan R, Comai G, Le Roux I, Gomes D, Konge J, Dumas G, Cimper C, Tajbakhsh S (2013) Embryonic founders of adult muscle stem cells are primed by the determination gene Mrf4. Dev Biol 381(1):241-255. doi:10.1016/j.ydbio.2013.04.018

135. Wood WM, Etemad S, Yamamoto M, Goldhamer DJ (2013) MyoD-expressing progenitors are essential for skeletal myogenesis and satellite cell development. Dev Biol. doi:10.1016/j.ydbio.2013.09.012

136. Kanisicak O, Mendez JJ, Yamamoto S, Yamamoto M, Goldhamer DJ (2009) Progenitors of skeletal muscle satellite cells express the muscle determination gene, MyoD. Dev Biol 332(1):131-141

137. Relaix F, Montarras D, Zaffran S, Gayraud-Morel B, Rocancourt D, Tajbakhsh S, Mansouri A, Cumano A, Buckingham M (2006) Pax3 and Pax7 have distinct and overlapping functions in adult muscle progenitor cells. J Cell Biol 172(1):91-102. doi: 10.1083/jcb.200508044

138. Olguin HC, Olwin BB (2004) Pax-7 up-regulation inhibits myogenesis and cell cycle progression in satellite cells: a potential mechanism for self-renewal. Dev Biol 275(2):375-388. doi:10.1016/j.ydbio.2004.08.015

139. Kuang S, Charge SB, Seale P, Huh M, Rudnicki MA (2006) Distinct roles for Pax7 and Pax3 in adult regenerative myogenesis. J Cell Biol 172(1):103-113

140. Oustanina S, Hause G, Braun T (2004) Pax7 directs postnatal renewal and propagation of myogenic satellite cells but not their specification. EMBO J 23(16):3430-3439. doi:10.1038/sj.em boj.7600346

141. Lepper C, Conway SJ, Fan CM (2009) Adult satellite cells and embryonic muscle progenitors have distinct genetic requirements. Nature 460(7255):627-631. doi:10.1038/nature08209

142. von Maltzahn J, Jones AE, Parks RJ, Rudnicki MA (2013) Pax7 is critical for the normal function of satellite cells in adult skeletal muscle. Proc Natl Acad Sci USA. doi:10.1073/p nas. 1307680110
143. Gunther S, Kim J, Kostin S, Lepper C, Fan CM, Braun T (2013) Myf5-positive satellite cells contribute to pax7-dependent longterm maintenance of adult muscle stem cells. Cell Stem Cell. doi:10.1016/j.stem.2013.07.016

144. Beauchamp JR, Heslop L, Yu DS, Tajbakhsh S, Kelly RG, Wernig A, Buckingham ME, Partridge TA, Zammit PS (2000) Expression of CD34 and Myf5 defines the majority of quiescent adult skeletal muscle satellite cells. J Cell Biol 151(6):1221-1234

145. Cornelison DD, Wold BJ (1997) Single-cell analysis of regulatory gene expression in quiescent and activated mouse skeletal muscle satellite cells. Dev Biol 191(2):270-283. doi:10.1006/d bio.1997.8721

146. Irintchev A, Zeschnigk M, Starzinski-Powitz A, Wernig A (1994) Expression pattern of M-cadherin in normal, denervated, and regenerating mouse muscles. Dev Dyn 199(4):326-337. doi :10.1002/aja.1001990407

147. Gnocchi VF, White RB, Ono Y, Ellis JA, Zammit PS (2009) Further characterisation of the molecular signature of quiescent and activated mouse muscle satellite cells. PLoS ONE 4(4):e5205. doi:10.1371/journal.pone.0005205

148. LaBarge MA, Blau HM (2002) Biological progression from adult bone marrow to mononucleate muscle stem cell to multinucleate muscle fiber in response to injury. Cell 111(4):589-601

149. Ratajczak MZ, Majka M, Kucia M, Drukala J, Pietrzkowski Z, Peiper S, Janowska-Wieczorek A (2003) Expression of functional CXCR4 by muscle satellite cells and secretion of SDF-1 by muscle-derived fibroblasts is associated with the presence of both muscle progenitors in bone marrow and hematopoietic stem/progenitor cells in muscles. Stem Cells 21(3):363-371. doi:10.1634/stemcells.21-3-363

150. Fukada S, Higuchi S, Segawa M, Koda K, Yamamoto Y, Tsujikawa K, Kohama Y, Uezumi A, Imamura M, Miyagoe-Suzuki Y, Takeda S, Yamamoto H (2004) Purification and cell-surface marker characterization of quiescent satellite cells from murine skeletal muscle by a novel monoclonal antibody. Exp Cell Res 296(2):245-255

151. Volonte D, Liu Y, Galbiati F (2005) The modulation of caveolin-1 expression controls satellite cell activation during muscle repair. FASEB J 19(2):237-239. doi:10.1096/fj.04-2215fje

152. Cornelison DD, Filla MS, Stanley HM, Rapraeger AC, Olwin BB (2001) Syndecan-3 and syndecan-4 specifically mark skeletal muscle satellite cells and are implicated in satellite cell maintenance and muscle regeneration. Dev Biol 239(1):79-94. doi:10.1006/dbio.2001.0416

153. Cornelison DD, Wilcox-Adelman SA, Goetinck PF, Rauvala H, Rapraeger AC, Olwin BB (2004) Essential and separable roles for Syndecan-3 and Syndecan-4 in skeletal muscle development and regeneration. Genes Dev 18(18):2231-2236. doi:10.1101/ gad. 1214204

154. Zammit PS, Heslop L, Hudon V, Rosenblatt JD, Tajbakhsh S, Buckingham ME, Beauchamp JR, Partridge TA (2002) Kinetics of myoblast proliferation show that resident satellite cells are competent to fully regenerate skeletal muscle fibers. Exp Cell Res 281(1):39-49

155. Crist CG, Montarras D, Buckingham M (2012) Muscle satellite cells are primed for myogenesis but maintain quiescence with sequestration of Myf5 mRNA targeted by microRNA-31 in mRNP granules. Cell Stem Cell 11(1):118-126. doi:10.1016/j. stem.2012.03.011

156. Gayraud-Morel B, Chretien F, Jory A, Sambasivan R, Negroni E, Flamant P, Soubigou G, Coppee JY, Di Santo J, Cumano A, Mouly V, Tajbakhsh S (2012) Myf5 haploinsufficiency reveals distinct cell fate potentials for adult skeletal muscle stem cells. J Cell Sci 125(Pt 7):1738-1749. doi:10.1242/jcs.097006 
157. Tidball JG, Villalta SA (2010) Regulatory interactions between muscle and the immune system during muscle regeneration. Am J Physiol Regul Integr Comp Physiol 298(5):R1173-R1187. doi :10.1152/ajpregu.00735.2009

158. Halevy O, Piestun Y, Allouh MZ, Rosser BW, Rinkevich Y, Reshef R, Rozenboim I, Wleklinski-Lee M, Yablonka-Reuveni $\mathrm{Z}$ (2004) Pattern of Pax7 expression during myogenesis in the posthatch chicken establishes a model for satellite cell differentiation and renewal. Dev Dyn 231(3):489-502. doi:10.1002/d vdy.20151

159. Zammit PS, Golding JP, Nagata Y, Hudon V, Partridge TA, Beauchamp JR (2004) Muscle satellite cells adopt divergent fates: a mechanism for self-renewal? J Cell Biol 166(3):347-357

160. Megeney LA, Kablar B, Garrett K, Anderson JE, Rudnicki MA (1996) MyoD is required for myogenic stem cell function in adult skeletal muscle. Genes Dev 10(10):1173-1183

161. White JD, Scaffidi A, Davies M, McGeachie J, Rudnicki MA, Grounds MD (2000) Myotube formation is delayed but not prevented in MyoD-deficient skeletal muscle: studies in regenerating whole muscle grafts of adult mice. J Histochem Cytochem 48(11):1531-1544

162. Fuchtbauer EM, Westphal H (1992) MyoD and myogenin are coexpressed in regenerating skeletal muscle of the mouse. Dev Dyn 193(1):34-39. doi:10.1002/aja.1001930106

163. Yablonka-Reuveni Z, Rivera AJ (1994) Temporal expression of regulatory and structural muscle proteins during myogenesis of satellite cells on isolated adult rat fibers. Dev Biol 164(2):588603. doi:10.1006/dbio.1994.1226

164. Gayraud-Morel B, Chretien F, Flamant P, Gomes D, Zammit PS, Tajbakhsh S (2007) A role for the myogenic determination gene Myf5 in adult regenerative myogenesis. Dev Biol 312(1):13-28. doi:10.1016/j.ydbio.2007.08.059

165. Knapp JR, Davie JK, Myer A, Meadows E, Olson EN, Klein WH (2006) Loss of myogenin in postnatal life leads to normal skeletal muscle but reduced body size. Development 133(4):601-610. doi:10.1242/dev.02249

166. Meadows E, Cho JH, Flynn JM, Klein WH (2008) Myogenin regulates a distinct genetic program in adult muscle stem cells. Dev Biol 322(2):406-414. doi:10.1016/j.ydbio.2008.07.024

167. Sartore S, Gorza L, Schiaffino S (1982) Fetal myosin heavy chains in regenerating muscle. Nature 298(5871):294-296

168. Schiaffino S, Gorza L, Dones I, Cornelio F, Sartore S (1986) Fetal myosin immunoreactivity in human dystrophic muscle. Muscle Nerve 9(1):51-58. doi:10.1002/mus.880090108

169. Kalhovde JM, Jerkovic R, Sefland I, Cordonnier C, Calabria E, Schiaffino S, Lomo T (2005) "Fast" and "slow" muscle fibres in hindlimb muscles of adult rats regenerate from intrinsically different satellite cells. J Physiol 562(Pt 3):847-857. doi:10.1113/j physiol.2004.073684

170. Whalen RG, Harris JB, Butler-Browne GS, Sesodia S (1990) Expression of myosin isoforms during notexin-induced regeneration of rat soleus muscles. Dev Biol 141(1):24-40

171. Shefer G, Van de Mark DP, Richardson JB, Yablonka-Reuveni Z (2006) Satellite-cell pool size does matter: defining the myogenic potency of aging skeletal muscle. Dev Biol 294(1):50-66. doi:10.1016/j.ydbio.2006.02.022

172. White RB, Bierinx AS, Gnocchi VF, Zammit PS (2010) Dynamics of muscle fibre growth during postnatal mouse development. BMC Dev Biol 10:21. doi:10.1186/1471-213X-10-21

173. Carlson BM, Faulkner JA (1989) Muscle transplantation between young and old rats: age of host determines recovery. Am J Physiol 256(6 Pt 1):C1262-C1266

174. Zacks SI, Sheff MF (1982) Age-related impeded regeneration of mouse minced anterior tibial muscle. Muscle Nerve 5(2):152161. doi:10.1002/mus. 880050213
175. Conboy IM, Conboy MJ, Wagers AJ, Girma ER, Weissman IL, Rando TA (2005) Rejuvenation of aged progenitor cells by exposure to a young systemic environment. Nature 433(7027):760-764. doi:10.1038/nature03260

176. Ferrari G, Cusella-De Angelis G, Coletta M, Paolucci E, Stornaiuolo A, Cossu G, Mavilio F (1998) Muscle regeneration by bone marrow-derived myogenic progenitors. Science 279(5356): $1528-1530$

177. Torrente Y, Belicchi M, Sampaolesi M, Pisati F, Meregalli M, D’Antona G, Tonlorenzi R, Porretti L, Gavina M, Mamchaoui K, Pellegrino MA, Furling D, Mouly V, Butler-Browne GS, Bottinelli R, Cossu G, Bresolin N (2004) Human circulating $\mathrm{AC} 133(+)$ stem cells restore dystrophin expression and ameliorate function in dystrophic skeletal muscle. J Clin Investig 114(2):182-195

178. Dezawa M, Ishikawa H, Itokazu Y, Yoshihara T, Hoshino M, Takeda S, Ide C, Nabeshima Y (2005) Bone marrow stromal cells generate muscle cells and repair muscle degeneration. Science 309(5732):314-317

179. Minasi MG, Riminucci M, De Angelis L, Borello U, Berarducci B, Innocenzi A, Caprioli A, Sirabella D, Baiocchi M, De Maria R, Boratto R, Jaffredo T, Broccoli V, Bianco P, Cossu G (2002) The meso-angioblast: a multipotent, self-renewing cell that originates from the dorsal aorta and differentiates into most mesodermal tissues. Development 129(11):2773-2783

180. Sampaolesi M, Torrente $\mathrm{Y}$, Innocenzi A, Tonlorenzi R, D'Antona G, Pellegrino MA, Barresi R, Bresolin N, De Angelis MG, Campbell KP, Bottinelli R, Cossu G (2003) Cell therapy of alpha-sarcoglycan null dystrophic mice through intra-arterial delivery of mesoangioblasts. Science 301(5632):487-492

181. Dellavalle A, Sampaolesi M, Tonlorenzi R, Tagliafico E, Sacchetti B, Perani L, Innocenzi A, Galvez BG, Messina G, Morosetti R, Li S, Belicchi M, Peretti G, Chamberlain JS, Wright WE, Torrente Y, Ferrari S, Bianco P, Cossu G (2007) Pericytes of human skeletal muscle are myogenic precursors distinct from satellite cells. Nat Cell Biol 9(3):255-267. doi: $10.1038 /$ ncb 1542

182. Pesce M, Orlandi A, Iachininoto MG, Straino S, Torella AR, Rizzuti V, Pompilio G, Bonanno G, Scambia G, Capogrossi MC (2003) Myoendothelial differentiation of human umbilical cord blood-derived stem cells in ischemic limb tissues. Circ Res 93(5):e51-e62

183. Mitchell KJ, Pannerec A, Cadot B, Parlakian A, Besson V, Gomes ER, Marazzi G, Sassoon DA (2010) Identification and characterization of a non-satellite cell muscle resident progenitor during postnatal development. Nat Cell Biol 12(3):257-266. doi: $10.1038 /$ ncb2025

184. Lepper C, Partridge TA, Fan CM (2011) An absolute requirement for Pax7-positive satellite cells in acute injury-induced skeletal muscle regeneration. Development 138(17):3639-3646. doi:10.1242/dev.067595

185. McCarthy JJ, Mula J, Miyazaki M, Erfani R, Garrison K, Farooqui AB, Srikuea R, Lawson BA, Grimes B, Keller C, Van Zant G, Campbell KS, Esser KA, Dupont-Versteegden EE, Peterson CA (2011) Effective fiber hypertrophy in satellite celldepleted skeletal muscle. Development 138(17):3657-3666. doi :10.1242/dev.068858

186. Murphy MM, Lawson JA, Mathew SJ, Hutcheson DA, Kardon G (2011) Satellite cells, connective tissue fibroblasts and their interactions are crucial for muscle regeneration. Development 138(17):3625-3637. doi:10.1242/dev.064162

187. Sambasivan R, Yao R, Kissenpfennig A, Van Wittenberghe L, Paldi A, Gayraud-Morel B, Guenou H, Malissen B, Tajbakhsh S, Galy A (2011) Pax7-expressing satellite cells are indispensable for adult skeletal muscle regeneration. Development 138(17):3647-3656. doi:10.1242/dev.067587 
188. Mommsen TP (2001) Paradigms of growth in fish. Comp Biochem Physiol B 129(2-3):207-219

189. Biga PR, Goetz FW (2006) Zebrafish and giant danio as models for muscle growth: determinate vs. indeterminate growth as determined by morphometric analysis. Am J Physiol Regul Integr Comp Physiol 291(5):R1327-R1337. doi:10.1152/ajpr egu.00905.2005

190. McPherron AC, Lee SJ (1997) Double muscling in cattle due to mutations in the myostatin gene. Proc Natl Acad Sci USA 94(23):12457-12461

191. Xu C, Wu G, Zohar Y, Du SJ (2003) Analysis of myostatin gene structure, expression and function in zebrafish. J Exp Biol 206(Pt 22):4067-4079

192. Acosta J, Carpio Y, Borroto I, Gonzalez O, Estrada MP (2005) Myostatin gene silenced by RNAi show a zebrafish giant phenotype. J Biotechnol 119(4):324-331. doi:10.1016/j.jbiotec.2005.04.023

193. Lee CY, Hu SY, Gong HY, Chen MH, Lu JK, Wu JL (2009) Suppression of myostatin with vector-based RNA interference causes a double-muscle effect in transgenic zebrafish. Biochem Biophys Res Commun 387(4):766-771. doi:10.1016/j.bbrc.2009.07.110

194. Maccatrozzo L, Bargelloni L, Radaelli G, Mascarello F, Patarnello $\mathrm{T}$ (2001) Characterization of the myostatin gene in the gilthead seabream (Sparus aurata): sequence, genomic structure, and expression pattern. Mar Biotechnol 3(3):224-230. doi:10.1007/s101260000064

195. Rodgers BD, Weber GM, Sullivan CV, Levine MA (2001) Isolation and characterization of myostatin complementary deoxyribonucleic acid clones from two commercially important fish: Oreochromis mossambicus and Morone chrysops. Endocrinology 142(4):1412-1418
196. Rodrigues AM, Christen B, Marti M, Izpisua Belmonte JC (2012) Skeletal muscle regeneration in Xenopus tadpoles and zebrafish larvae. BMC Dev Biol 12:9. doi:10.1186/1471-213X-12-9

197. Seger C, Hargrave M, Wang X, Chai RJ, Elworthy S, Ingham PW (2011) Analysis of Pax7 expressing myogenic cells in zebrafish muscle development, injury, and models of disease. Dev Dyn 240(11):2440-2451. doi:10.1002/dvdy.22745

198. Froehlich JM, Galt NJ, Charging MJ, Meyer BM, Biga PR (2013) In vitro indeterminate teleost myogenesis appears to be dependent on Pax3. In Vitro Cell Dev Biol Anim 49(5):371385. doi:10.1007/s11626-013-9616-2

199. Otten C, van der Ven PF, Lewrenz I, Paul S, Steinhagen A, Busch-Nentwich E, Eichhorst J, Wiesner B, Stemple D, Strahle U, Furst DO, Abdelilah-Seyfried S (2012) Xirp proteins mark injured skeletal muscle in zebrafish. PLoS ONE 7(2):e31041. doi:10.1371/journal.pone.0031041

200. Hawke TJ, Atkinson DJ, Kanatous SB, Van der Ven PF, Goetsch SC, Garry DJ (2007) Xin, an actin binding protein, is expressed within muscle satellite cells and newly regenerated skeletal muscle fibers. Am J Physiol Cell Physiol 293(5):C1636-C1644. doi:10.1152/ajpcell.00124.2007

201. Rowlerson A, Radaelli G, Mascarello F, Veggetti A (1997) Regeneration of skeletal muscle in two teleost fish: Sparus aurata and Brachydanio rerio. Cell Tissue Res 289(2):311-322

202. Berger J, Berger S, Hall TE, Lieschke GJ, Currie PD (2010) Dystrophin-deficient zebrafish feature aspects of the Duchenne muscular dystrophy pathology. Neuromuscul Disord 20(12):826-832. doi:10.1016/j.nmd.2010.08.004 